\title{
Equilibrium and kinetics studies on bibrachial lariat aza-crown/Cu(II) systems reveal different behavior associated with small changes in the structure
}

\author{
Carmen E. Castillo a, Andrés G. Algarra ${ }^{a}$, Armando Ferrer ${ }^{a, 1}$, M. Angeles Máñez ${ }^{a}$, Manuel G. Basallote ${ }^{a, *}$, \\ M. Paz Clares ${ }^{b}$, Concepción Soriano ${ }^{c}$, M. Teresa Albelda ${ }^{\mathrm{b}}$, Enrique García-España ${ }^{\mathrm{b}, *}$ \\ ${ }^{a}$ Departamento de Ciencia de los Materiales e Ingeniería Metalúrgica y Química Inorgánica, Facultad de Ciencias, Universidad de Cádiz, \\ Avenida República Saharahui s/n, Puerto Real, 11510 Cádiz, Spain \\ ${ }^{\mathrm{b}}$ Instituto de Ciencia Molecular, Universidad de Valencia, C/Catedrático José Beltrán 2, 46980 Paterna (Valencia), Spain \\ ${ }^{\mathrm{c}}$ Departamento de Química Orgánica, Facultad de Farmacia, Avenida Vicent Andrés Estellés s/n, 46100 Burjassot (Valencia), Spain
}

\section{A R T I C L E I N F O}

\section{Article history:}

Available online 29 December 2013

Metals In Supramolecular Chemistry Special Issue

\section{Keywords:}

Azacrown

Macrocycle

Copper(II)

Coordination geometry

Potentiometric equilibrium studies

Kinetics

\begin{abstract}
A B S T R A C T
The high-yield synthesis of a new bibrachial lariat azacrown constituted by two tris(2-aminoethyl)amine (tren) units functionalized in one of its arms with a 4-methylquinoline group linked by dimethylene pyridine spacers (L2) is reported for the first time. The speciation studies show formation of mono- and binuclear $\mathrm{Cu}^{2+}$ complexes of similar stability. Comparisons are established with the complexes formed by the precursor tren-quinoline derivative $(\mathbf{L} \mathbf{4})$ and with the previously reported ligands containing naphthalene instead of quinoline as the fluorophore (L1, L3). The kinetics of formation and decomposition of $\mathrm{Cu}^{2+}$ complexes with $\mathbf{L 1}$ and $\mathbf{L 2}$ has been studied. For L1, the acid-promoted decomposition of mono and dinuclear complexes occurs in all cases with a rapid step within the stopped-flow mixing time that leads to the formation of an intermediate that decomposes in two additional steps. In the dinuclear complexes, both metal ions dissociate from the ligand with statistically-controlled kinetics. Complex formation with $\mathbf{L 1}$ occurs through the same intermediate observed during the decomposition. For L2, only the formation and decomposition of binuclear complexes could be studied, and the kinetic data show that the metal ion can coordinate both in square pyramidal $s p$ and trigonal bipyramidal (tbp) geometries, coordination being faster in the $s p$ environment and dissociation being faster from tbp. DFT and TD-DFT have been also carried out to determine the geometries with both coordination environments as well as their electronic spectra. The results of calculations indicate that the appearance or not of a mixture of coordination geometries does not necessarily require the participation of the quinoline ring.
\end{abstract}

(c) 2013 Elsevier B.V. All rights reserved.

\section{Introduction}

The so-called brachial lariat ethers were built with the idea to join encapsulating ability with rapid association and dissociation kinetics so that associated substrates can be transported and delivered in an efficient way [1,2]. A few years ago some of us reported the synthesis, copper coordination, anion coordination and photochemical properties of the bibrachial azacrown L1 (Scheme 1) [3,4]. The presence of only nitrogen donors in $\mathbf{L 1}$ switches its binding ability from the harder alkaline and alkaline earth metal ions preferred by lariat ethers to the softer transition metal ions [5].

\footnotetext{
* Corresponding authors. Tel.: +34 956012739 (M.G. Basallote). Tel.: +34 963 544879 (E. García-España).

E-mail addresses: aferrer@cnt.uo.edu.cu (A. Ferrer), manuel.basallote@uca.es (M.G. Basallote), enrique.garcia-es@uv.es (E. García-España).

1 Present address: Departamento de Química, Facultad de Ciencias Naturales, Universidad de Oriente, Avda. Patricio Lumumba s/n, 90500 Santiago de Cuba, Cuba.
}

L1 displays interesting chemistry and photochemical properties regarding the relative motions and arrangements adopted by the side chains containing the fluorophoric naphthalene moieties with respect to the macrocyclic core. Such reorganizations brought about by changes in $\mathrm{pH}$ and metal coordination can be of relevance regarding the interaction of $\mathbf{L 1}$, either in its free form or filled with substrates, with other molecules of biological relevance such as nucleotides, nucleic acids or proteins [6-9]. Following this idea, we thought that analogous receptors in which the condensed aromatic ring at the side arms presented donor atoms outwardly oriented may facilitate the interaction with further molecules. To do so we have prepared a new macrocycle of this series containing 4-quinoline substituents (L2). For comparative purposes, we have also isolated its synthetic precursor (L4) built up linking a quinoline ring through its 4-position to one of the branches of the tripodal polyamine tris(2-aminoethyl)amine (tren). Furthermore, quinoline derivatives have demonstrated great relevance in 


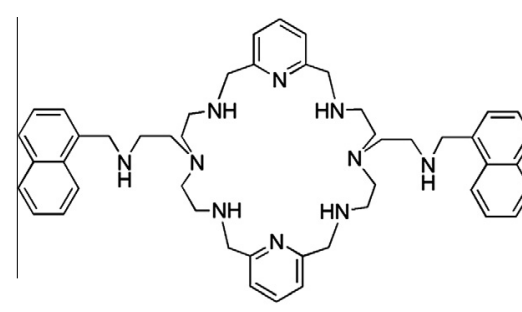

L1

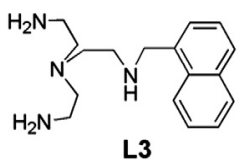

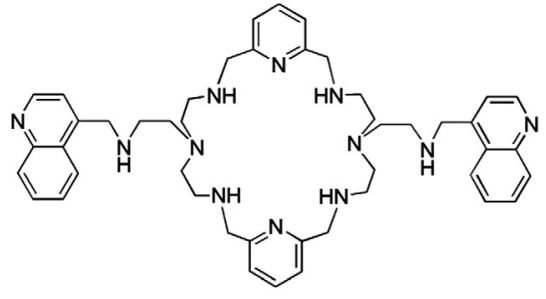

L2

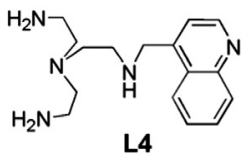

Scheme 1.

medicinal chemistry, in particular, regarding their potential actuation as drugs for the treatment of malaria, arthritis, Alzheimer and cancer [10-15]. Besides the synthetic procedure and characterization of the compounds, we describe the $\mathrm{Cu}^{2+}$ coordination chemistry of these two new compounds. Finally, as kinetics is a key aspect of the chemistry of this kind of compounds, we provide a detailed kinetic analysis of the $\mathrm{Cu}^{2+}$ coordination with $\mathbf{L 1}$ and $\mathbf{L 2}$, both in the formation and dissociation directions. The whole set of equilibrium and kinetic information allows us to discuss how the presence of the heteroatom has a drastic influence on molecular reorganization and $\mathrm{Cu}^{2+}$ coordination.

\section{Experimental}

\subsection{Synthesis of the ligands}

L1 and L3 were synthesized as described in Ref. [3] and isolated as their perchlorate and hydrochloride salts, respectively.

CAUTION: Perchlorate salts of organic compounds might be explosive and should be handled with care.

\subsubsection{Synthesis of $\mathrm{L} 4 \cdot 4 \mathrm{HC} 1 \cdot 1.5 \mathrm{H}_{2} \mathrm{O}$}

Quinoline-4-carbaldehyde (0.51 g, $3.2 \mathrm{mmol})$ and $\mathrm{N}^{1}, \mathrm{~N}^{1}$-bis(2aminoethyl)ethane-1,2-diamine $(1.40 \mathrm{~g}, 9.60 \mathrm{mmol})$ were dissolved in $100 \mathrm{~mL}$ of $\mathrm{EtOH}-\mathrm{CH}_{3} \mathrm{CN}$ (1:1). The resulting solution was stirred for $2 \mathrm{~h}$ and then the solvent evaporated. The obtained residue was dissolved in EtOH and $\mathrm{NaBH}_{4}(1.12 \mathrm{~g}, 29.5 \mathrm{mmol})$ was added portion wise. After two hours at room temperature the solvent was evaporated to dryness. The resulting residue was treated with water and repeatedly extracted with dichloromethane $(3 \times 50 \mathrm{~mL})$. The organic phase was then dried with anhydrous sodium sulfate and the solvent evaporated to yield the free amine as an oil. The oil was then taken in a minimum amount of EtOH and precipitated with aqueous $\mathrm{HCl}$ as its hydrochloride salt (yield 73\%). $\mathrm{mp}=210-212{ }^{\circ} \mathrm{C} .{ }^{1} \mathrm{H}$ NMR $\delta_{\mathrm{H}}(\mathrm{ppm}): 2.94(\mathrm{t}, 4 \mathrm{H}, J=6 \mathrm{~Hz}), 3.06(\mathrm{t}$, $2 \mathrm{H}, J=7 \mathrm{~Hz}), 3.18(\mathrm{t}, 4 \mathrm{H}, J=6 \mathrm{~Hz}), 3,51(\mathrm{t}, 2 \mathrm{H}, J=7 \mathrm{~Hz}), 5.10$ $(\mathrm{s}, 2 \mathrm{H}), 8.01-8.07(\mathrm{~m}, 2 \mathrm{H}), 8.17(\mathrm{t}, 1 \mathrm{H}, J=7 \mathrm{~Hz}), 8.30(\mathrm{~d}, 1 \mathrm{H}$ $J=8 \mathrm{~Hz}), 8.39$ (d, $1 \mathrm{H}, J=8 \mathrm{~Hz}) \cdot{ }^{13} \mathrm{C}$ NMR $\delta_{\mathrm{c}}(\mathrm{ppm}): 36.88,45.55$, $47.38,48.80,50.09,121.75,122.66,124.35,131.07,135.27$, 144.97. Anal. Calc. for $\mathrm{C}_{16} \mathrm{H}_{29} \mathrm{~N}_{5} \mathrm{Cl}_{4} \cdot 1.5 \mathrm{H}_{2} \mathrm{O}: \mathrm{C}, 41.77, \mathrm{H}, 6.96, \mathrm{~N}$ 15.22. Found: C, $42.0, \mathrm{H}, 6.9, \mathrm{~N}, 14.9 \%$.

\subsubsection{Synthesis of $\mathrm{L} 2 \cdot 6 \mathrm{HClO}_{4} \cdot 4 \mathrm{H}_{2} \mathrm{O}$}

2,6-Pyridine dicarbaldehyde $(0.80 \mathrm{~g}, 5.59 \mathrm{mmol})$ dissolved in $100 \mathrm{~mL}$ of EtOH was dropwise added to a solution of $\mathbf{L 4}(1.60 \mathrm{~g}$, $5.59 \mathrm{mmol})$ in EtOH and stirred for $1 \mathrm{~h}$. Solid $\mathrm{NaBH}_{4}(1.84 \mathrm{~g}$, $45.4 \mathrm{mmol}$ ) was then added portion wise. After $2 \mathrm{~h}$ the solvent was evaporated to dryness. The residue was treated with water and repeatedly extracted with $\mathrm{CH}_{2} \mathrm{Cl}_{2}(3 \times 40 \mathrm{~mL})$. The organic phase was dried with anhydrous sodium sulfate and the solvent evaporated to dryness to yield a yellowish oil. The oil was then taken in a minimum amount of EtOH and precipitated with aqueous $\mathrm{HClO}_{4}$ as its hydrochloride salt (yield 66\%). mp: $210-213^{\circ} \mathrm{C} .{ }^{1} \mathrm{H}$ NMR $\delta_{\mathrm{H}}(\mathrm{ppm}): 2.93-3.05(\mathrm{~m}, 12 \mathrm{H}), 3.29-3.35(\mathrm{~m}, 12 \mathrm{H}), 4.38(\mathrm{~s}$, $8 \mathrm{H}), 7.43(\mathrm{~d}, 4 \mathrm{H}, J=8 \mathrm{~Hz}), 7.60(\mathrm{~d}, 2 \mathrm{H}, J=4 \mathrm{~Hz}), 7.71(\mathrm{t}, 2 \mathrm{H}$, $J=8 \mathrm{~Hz}), 7.82-7.93(\mathrm{~m}, 4 \mathrm{H}), 8.07(\mathrm{t}, 4 \mathrm{H}, J=8 \mathrm{~Hz}), 8.83(\mathrm{~d}, 2 \mathrm{H}$, $J=4 \mathrm{~Hz}) .{ }^{13} \mathrm{C}$ NMR $\delta_{\mathrm{c}}(\mathrm{ppm}): 44.5,44.7,48.3,49.1,50.9,121.9$, 123.3, 127.1, 128.8, 131.8, 139.5, 148.6. Anal. Calc. For $\mathrm{C}_{46} \mathrm{H}_{66} \mathrm{~N}_{12-}$ $\mathrm{Cl}_{6} \mathrm{O}_{24} \cdot 4 \mathrm{H}_{2} \mathrm{O}: \mathrm{C}, 37.95, \mathrm{H}, 5.12, \mathrm{~N}, 11.54$. Found: $\mathrm{C}, 38.1, \mathrm{H}, 5.1, \mathrm{~N}$, $11.9 \%$.

\subsection{NMR measurements}

The ${ }^{1} \mathrm{H}$ and ${ }^{13} \mathrm{C}$ NMR spectra were recorded on Bruker Advance DPX $300 \mathrm{MHz}$ and Bruker Advance DPX $400 \mathrm{MHz}$ spectrometers operating at $299.95 \mathrm{MHz}$ and $399.95 \mathrm{MHz}$ for ${ }^{1} \mathrm{H}$ and at $75.43 \mathrm{MHz}$ and $100.58 \mathrm{MHz}$ for ${ }^{13} \mathrm{C}$. tert-butyl alcohol was used as a reference standard $\left(\delta=1.24 \mathrm{ppm}\right.$ for ${ }^{1} \mathrm{H}$ and $\delta=70.36 \mathrm{ppm}$ for ${ }^{13} \mathrm{C}$, respectively) [16]. Adjustments to the desired $\mathrm{pH}$ were made using drops of $\mathrm{DCl}$ or NaOD solutions. The $\mathrm{pD}$ was calculated from the measured $\mathrm{pH}$ values using the correlation $\mathrm{pH}=\mathrm{pD}-0.4$ [17].

\subsection{Equilibrium studies}

The potentiometric titrations were carried out at $298.1 \pm 0.1 \mathrm{~K}$ using $0.15 \mathrm{M} \mathrm{NaCl}$ as supporting electrolyte. The experimental procedure (buret, potentiometer, cell, stirrer, microcomputer, etc.) has been fully described elsewhere [3]. The reference electrode was an $\mathrm{Ag} / \mathrm{AgCl}$ electrode in saturated $\mathrm{KCl}$ solution. The glass electrode was calibrated as a hydrogen-ion concentration probe by titration of previously standardized amounts of $\mathrm{HCl}$ with $\mathrm{CO}_{2}$-free $\mathrm{NaOH}$ solutions and the equivalent point determined by Gran's method $[18,19]$, which gives the standard potential, $E^{\circ}$, and the ionic product of water $\left(\mathrm{p} K_{\mathrm{w}}=13.73(1)\right)$. The acquisition of the emf data was performed with the computer program PASAT [20].

The computer program HYPERQUAD was used to calculate the protonation and stability constants [21,22]. The $\mathrm{pH}$ range investigated was $2.0-11.0$, and the concentration of the metal ions and of the ligands ranged from $1 \times 10^{-3}$ to $5 \times 10^{-3} \mathrm{M}$ with M:L molar ratios varying from $2: 1$ to $1: 2$. The different titration curves for each system (at least two) were treated either as a single set or as separated curves without significant variations in the values of the stability constants. Finally, the sets of data were merged together and treated simultaneously to give the final stability constants. 


\subsection{Kinetic studies}

The kinetic experiments were conducted at $298.1 \pm 0.1 \mathrm{~K}$ in the presence of $0.15 \mathrm{M}$ supporting electrolyte with either a Cary 50BIO spectrophotometer or an Applied Photophysics SX17MV stopped-flow instrument provided with a PDA-1 diode array detector. In both cases, the kinetic experiments provided spectral changes with time that were analyzed using global analysis procedures with the SPECFIT software [23]. All solutions for the kinetic work on complex decomposition contained $\mathrm{Cu}^{2+}$ and the ligand in $1: 1$ or $2: 1 \mathrm{M}$ ratio $\left([\mathrm{Cu}]_{0}=4-8 \times 10^{-4} \mathrm{M}\right.$ and $\left.[\mathrm{L}]_{0}=4 \times 10^{-4} \mathrm{M}\right)$, the $\mathrm{pH}$ being adjusted with $\mathrm{NaOH}$ to values at which the species distribution curves indicate that the concentration of the complexes achieve a maximum in solution. For kinetic studies on complex formation, a solution of the ligand $\left([\mathrm{L}]_{0}=4 \times 10^{-4} \mathrm{M}\right)$ whose $\mathrm{pH}$ had been previously adjusted with $\mathrm{HCl}$ or $\mathrm{NaOH}$ solutions was mixed in the stopped-flow instrument with a solution containing 1 or 2 equivalents of $\mathrm{Cu}^{2+}$ with the $\mathrm{pH}$ adjusted at the same value. No buffers were added because it has been previously shown that buffering agents can interact with either the metal ion or the protonated forms of polyamine ligands [24]. Because of the absence of buffers the reactions of complex formation occur with changes in the concentration of protons, which were taken into account by introducing them in the kinetic model used to analyse the data.

\subsection{Computational details}

All DFT calculations were carried out with the Gaussian 09 software package [25] using the B3LYP hybrid functional [26,27]. Spin unrestricted calculations were performed for the paramagnetic species. The Stuttgart-Dresden SDD basis set [28] was used with a relativistic effective core potential for copper, and all ligand atoms $(\mathrm{C}, \mathrm{N}, \mathrm{O}, \mathrm{H})$ were described by the Pople-style basis set 6 $31 \mathrm{G}(\mathrm{d}, \mathrm{p})$ [29]. Test calculations with the nonhybrid BP86 functional gave very similar results, and so the hybrid B3LYP functional was used to allow for comparison with previous work [30]. All geometry optimizations were performed without any symmetry constraints and efforts were made to find the lowest energy conformations by comparing the structures optimized from different starting geometries. Optimizations were performed with the effects of the aqueous phase $(\varepsilon=78.39)$ included self-consistently through the conductor-like polarisable continuum model (CPCM) [31] as implemented in Gaussian 09 [25]. The energies given in the text correspond to free energies in solution at $298.15 \mathrm{~K}$, and include dispersion energy corrections (D3) [32] obtained by single-point calculations on the optimized structures.

The electronic absorption spectra of the previously optimized species were calculated by using the time-dependent DFT (TDDFT) formalism [33] at the same computational level. The nonspecific solvent effect was considered in the TD-DFT calculations via the nonequilibrium version of the CPCM algorithm [31]. The energy and oscillator strength of the lowest 30 singlet-excited-state transitions were calculated for each complex. GaussSum 2.2 was employed to draw the absorption spectra (full width at half maximum $=3000 \mathrm{~cm}^{-1}$ ) [34].

\section{Results and discussion}

\subsection{Equilibrium studies on ligand protonation and formation of $\mathrm{Cu}^{2+}$ complexes}

The equilibrium constants for the protonation of $\mathbf{L 2}, \mathbf{L} \mathbf{4}$ and the formation of their $\mathrm{Cu}^{2+}$ complexes were determined by potentiometric titrations and the results are included in Tables 1 and 2. For comparison, the data corresponding to the related ligands L1 and $\mathbf{L} 3$ systems previously reported are also included [3].
Table 1

Protonation constants of the systems L1, L2, L3 and $\mathbf{L 4}$ determined in $0.15 \mathrm{M} \mathrm{NaCl}$ at $298.1 \mathrm{~K}$.

\begin{tabular}{lllll}
\hline Reaction & L1 & L3 & L2 & L4 \\
\hline $\mathrm{H}+\mathrm{L} \leftrightarrows \mathrm{HL}$ & $9.45(3)$ & $9.72(1)$ & $9.10(3)$ & $9.74(1)$ \\
$\mathrm{HL}+\mathrm{H} \leftrightarrows \mathrm{H}_{2} \mathrm{~L}$ & $8.47(4)$ & $9.10(1)$ & $8.66(3)$ & $9.08(1)$ \\
$\mathrm{H}_{2} \mathrm{~L}+\mathrm{H} \leftrightarrows \mathrm{H}_{3} \mathrm{~L}$ & $7.65(5)$ & $7.45(1)$ & $7.50(3)$ & $6.61(1)$ \\
$\mathrm{H}_{3} \mathrm{~L}+\mathrm{H} \leftrightarrows \mathrm{H}_{4} \mathrm{~L}$ & $7.25(7)$ & - & $7.12(4)$ & $3.43(1)$ \\
$\mathrm{H}_{4} \mathrm{~L}+\mathrm{H} \leftrightarrows \mathrm{H}_{5} \mathrm{~L}$ & $6.50(5)$ & - & $6.50(4)$ & \\
$\mathrm{H}_{5} \mathrm{~L}+\mathrm{H} \leftrightarrows \mathrm{H}_{6} \mathrm{~L}$ & $6.29(6)$ & & $6.02(3)$ & \\
$\mathrm{H}_{6} \mathrm{~L}+\mathrm{H} \leftrightarrows \mathrm{H}_{7} \mathrm{~L}$ & & & $4.07(3)$ & \\
$\mathrm{H}_{7} \mathrm{~L}+\mathrm{H} \leftrightarrows \mathrm{H}_{8} \mathrm{~L}$ & & & $2.81(5)$ & \\
\hline
\end{tabular}

Table 2

Stability constants for the formation of $\mathrm{Cu}^{2+}$ complexes of the systems $\mathbf{L 1}, \mathbf{L 2}, \mathbf{L 3}$ and L4 determined in $0.15 \mathrm{M} \mathrm{NaCl}$ at $298.1 \mathrm{~K}$.

\begin{tabular}{lllll}
\hline Reaction & L1 & L3 & L2 & L4 \\
\hline $\mathrm{Cu}+\mathrm{L} \leftrightarrows \mathrm{CuL}$ & $20.13(9)$ & $17.43(1)$ & $16.0(1)$ & $16.92(1)$ \\
$\mathrm{CuL}+\mathrm{H} \leftrightarrows \mathrm{Cu}(\mathrm{HL})$ & $8.84(8)$ & $3.82(2)$ & $8.7(2)$ & $4.71(4)$ \\
$\mathrm{Cu}(\mathrm{HL})+\mathrm{H} \leftrightarrows \mathrm{Cu}\left(\mathrm{H}_{2} \mathrm{~L}\right)$ & $7.12(7)$ & - & $7.3(1)$ & $3.34(1)$ \\
$\mathrm{Cu}\left(\mathrm{H}_{2} \mathrm{~L}\right)+\mathrm{H} \leftrightarrows \mathrm{Cu}\left(\mathrm{H}_{3} \mathrm{~L}\right)$ & $5.09(5)$ & - & - & - \\
$2 \mathrm{Cu}+\mathrm{L} \leftrightarrows \mathrm{Cu}_{2} \mathrm{~L}$ & $31.05(8)$ & & $31.54(7)$ & \\
$\mathrm{CuL}+\mathrm{Cu} \leftrightarrows \mathrm{Cu}_{2} \mathrm{~L}$ & $10.93(9)$ & - & $15.6(1)$ & - \\
$\mathrm{Cu}_{2} \mathrm{~L}+\mathrm{H} \leftrightarrows \mathrm{Cu}_{2}(\mathrm{HL})$ & $6.91(5)$ & - & $4.87(9)$ & - \\
$\mathrm{Cu}_{2}(\mathrm{HL})+\mathrm{H} \leftrightarrows \mathrm{Cu}_{2}\left(\mathrm{H}_{2} \mathrm{~L}\right)$ & $3.3(1)$ & - & $4.70(5)$ & - \\
$\mathrm{Cu}_{2} \mathrm{~L}+\mathrm{H}_{2} \mathrm{O} \leftrightarrows \mathrm{Cu}_{2} \mathrm{~L}(\mathrm{OH})+\mathrm{H}$ & $-9.9(1)$ & - & $-9.5(1)$ & - \\
$\mathrm{Cu}_{2} \mathrm{~L}(\mathrm{OH})+\mathrm{H}_{2} \mathrm{O} \leftrightarrows \mathrm{Cu} \mathrm{Cu}_{2} \mathrm{~L}(\mathrm{OH})_{2}+\mathrm{H}$ & $-10.0(1)$ & - & - & - \\
\hline
\end{tabular}

Under the experimental conditions used L2 displays eight measurable protonation constants in the range of 9.10-2.82 logarithmic units (Table 1, Fig. 1B). Taking into account the values reported and the average protonation mechanism previously described for the related ligand L1, which has naphthalene instead of quinoline rings at the side chains, the first six protonation constants should mainly involve the secondary nitrogen atoms of the macrocyclic core and lateral chains. The last two protonation steps should be involving the quinoline nitrogen atoms placed at the 4position. The pyridine nitrogen atoms are not prone to bear protonation processes in the $\mathrm{pH}$ range covered in this study as it has been evidenced for related macrocyclic ligands [35-38]. Examination of the data obtained for the acyclic ligand $\mathbf{L 4}$, in which the tripodal polyamine tris(2-aminoethyl)amine (tren) has been monofunctionalised with a quinoline ring, shows as this ligand has four protonation constants. The two first two protonation constants, which are slightly higher than those of $\mathbf{L 2}$, involve predominantly the primary amine groups while the third one implicates the secondary amine of the arm functionalized with quinoline.

The higher basicity of the primary amino groups is usually ascribed to a better stabilization of the positive charge by hydrogen bonding with water molecules [37]. The fourth protonation step, which is intermediate between those found for the seventh and eight protonation steps of $\mathbf{L 2}$, should affect mainly to the quinoline nitrogen. Indeed, the open-chain ligand $\mathbf{L} 3$ having a naphthalene unit instead of a quinoline moiety, presents just three protonation constants. The protonation sequence of $\mathbf{L} \mathbf{4}$ has been followed by ${ }^{1} \mathrm{H}$ and ${ }^{13} \mathrm{C}$ NMR spectroscopies (see Fig. 2 and Fig. S1 in the Supplementary information) recorded in $\mathrm{D}_{2} \mathrm{O}$. The ${ }^{1} \mathrm{H}$ singlet signals attributed to protons labeled as $\mathrm{H} 4$ and $\mathrm{H5}$, both placed in $\alpha$-position with respect to $\mathrm{N4}$, experience their greatest downfield shifts $\left(\Delta \delta_{\mathrm{H}}=0.51\right.$ and $0.54 \mathrm{ppm}$, respectively) on going from pD 7.6 to $\mathrm{pD}$ 4.4 suggesting the protonation of the secondary amine group (N4) in the third step. This is supported by the corresponding upfield shifts observed in the ${ }^{13} \mathrm{C}$ NMR spectra for carbon atom $\mathrm{C} 3$ $\left(\Delta \delta_{\mathrm{C}}=2.93 \mathrm{ppm}\right)$ placed in $\beta$-position with respect to N4. Protonation of the quinoline ring in the last step is supported by the 
upfield shifts of the ${ }^{1} \mathrm{H}$ NMR signals of the aromatic protons q3 $\left(\Delta \delta_{\mathrm{H}}=0.28 \mathrm{ppm}\right)$ and the downfield shifts of the ${ }^{13} \mathrm{C}$ NMR signals of the aromatic carbon $\mathrm{Cq} 3\left(\Delta \delta_{\mathrm{C}}=5.53 \mathrm{ppm}\right)$ observed below $\mathrm{pH} 4$.

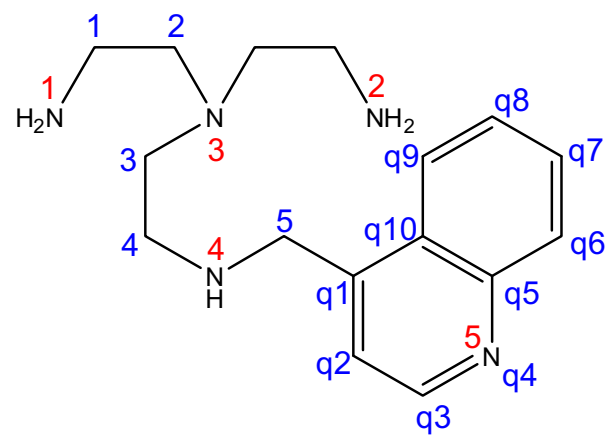

In spite of the relatively close structures of $\mathbf{L 1}$ and $\mathbf{L 2}$ very significant differences are found in the $\mathrm{Cu}^{2+}$ speciation studies. While for both systems the stoichiometry and protonation degrees are essentially the same, with the exception of the presence of a further protonated mononuclear species and of a further hydroxylated binuclear species for $\mathbf{L 1}$ (see Table 2 and Fig. 3), the stability of some of the species formed is rather different. Particularly the stability constant for the formation of the mononuclear $\mathrm{CuL}^{2+}$ species is four orders of magnitude greater for $\mathbf{L 1}$ than for $\mathbf{L 2}$ $\left(\log K=20.13(9)\right.$ and $16.0(1)$, respectively). While the $\mathrm{CuL}^{2+}$ complex formed by $\mathbf{L 1}$ is two orders of magnitude more stable than the one formed by its related open-chain polyamine L3, the $\mathrm{CuL}^{2+}$ of $\mathbf{L} \mathbf{2}$ and $\mathbf{L} \mathbf{4}$ present a much closer stability, being the complex of the macrocyclic ligand $\mathbf{L 2}$ even slightly less stable than that of L4. This has dramatic consequences in the profiles of the distribution diagrams. While for the system $\mathrm{Cu}^{2+}-\mathbf{L 1}$ mononuclear or binuclear species predominate in solution depending on the $\mathrm{Cu}^{2+}: \mathbf{L}$ molar ratio, for the system $\mathrm{Cu}^{2+}-\mathbf{L} \mathbf{2}$ the binuclear species start to prevail already in solution for $1: 1 \mathrm{Cu}^{2+}: \mathrm{L}$ molar ratio (see Fig. 3).
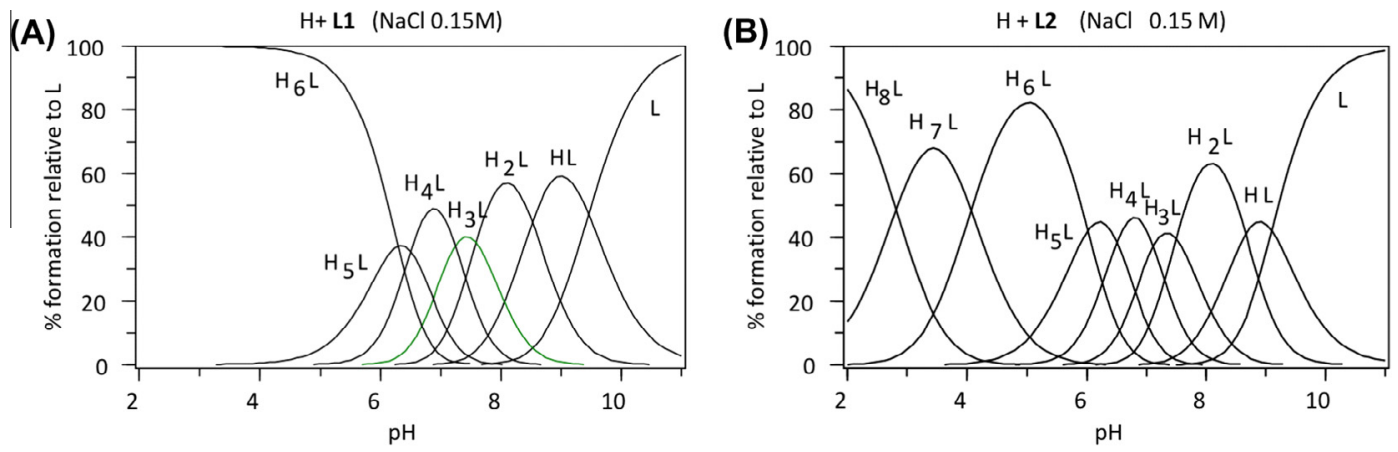

Fig. 1. Species distribution curves for the systems $(A) \mathrm{H}^{+}-\mathbf{L 1}$, (B) $\mathrm{H}^{+}-\mathbf{L 2}$. $[\mathbf{L 1}]=[\mathbf{L 2}]=1 \times 10^{-3} \mathrm{M}$.
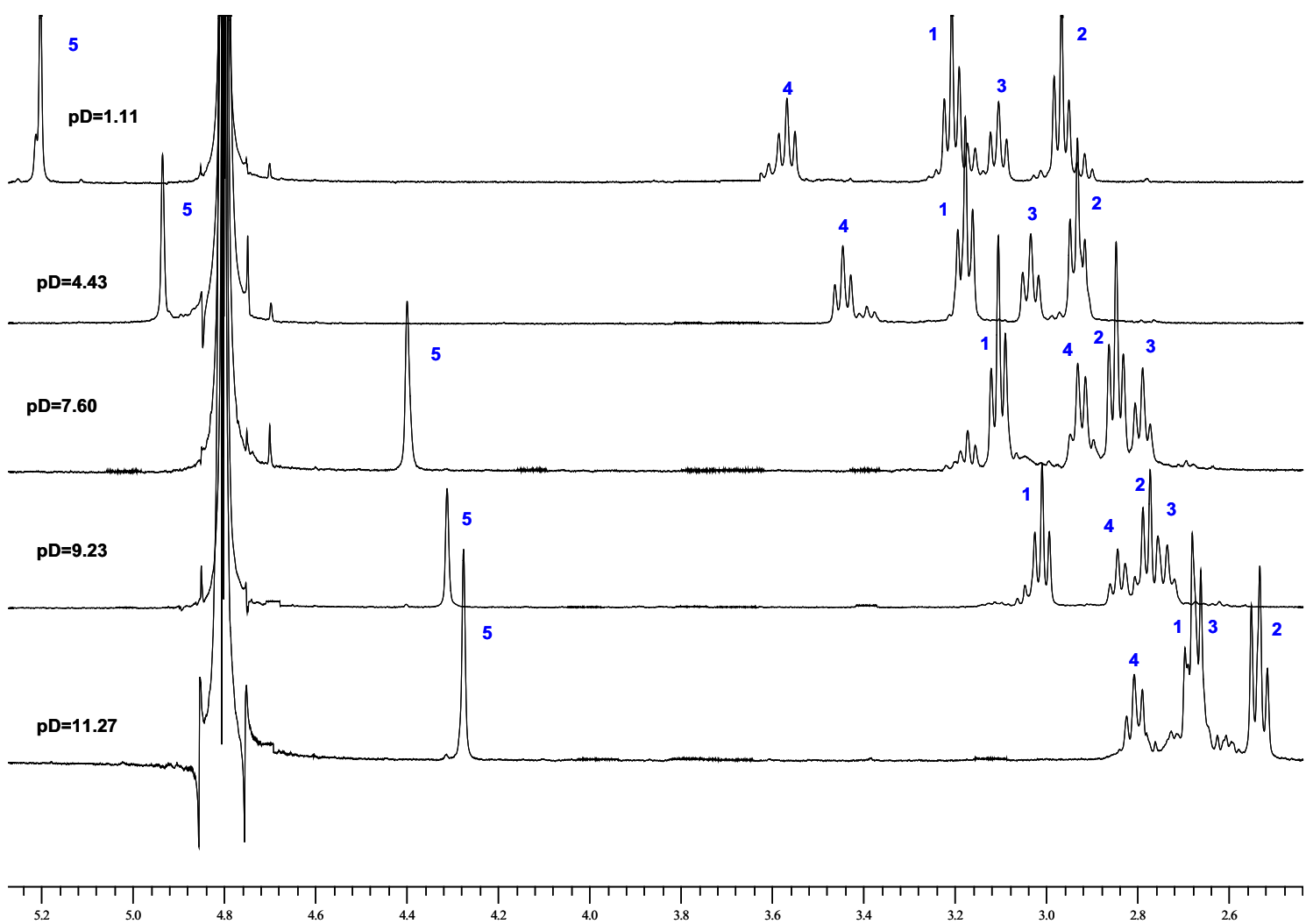

Fig. 2a. Aliphatic region of the ${ }^{1} \mathrm{H}$ NMR spectra of $\mathbf{L} 4$ recorded in $\mathrm{D}_{2} \mathrm{O}(\mathrm{pD}=1.11,4.43,7.60,9.23$ and 11.27). 

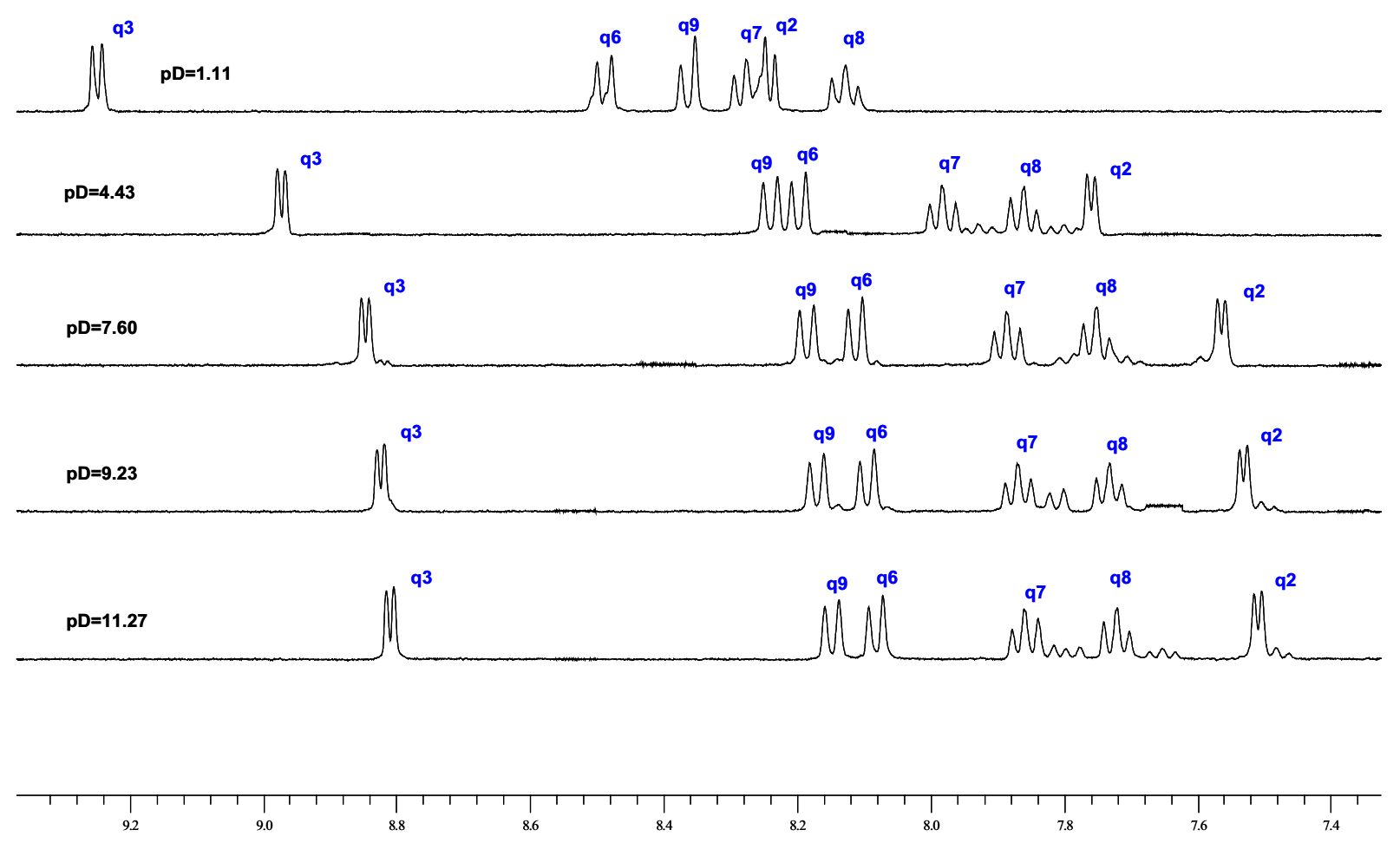

Fig. 2b. Aromatic region of the ${ }^{1} \mathrm{H}$ NMR spectra of $\mathbf{L} 4$ recorded in $\mathrm{D}_{2} \mathrm{O}(\mathrm{pD}=1.11,4.43,7.60,9.23$ and 11.27 ).

(A)

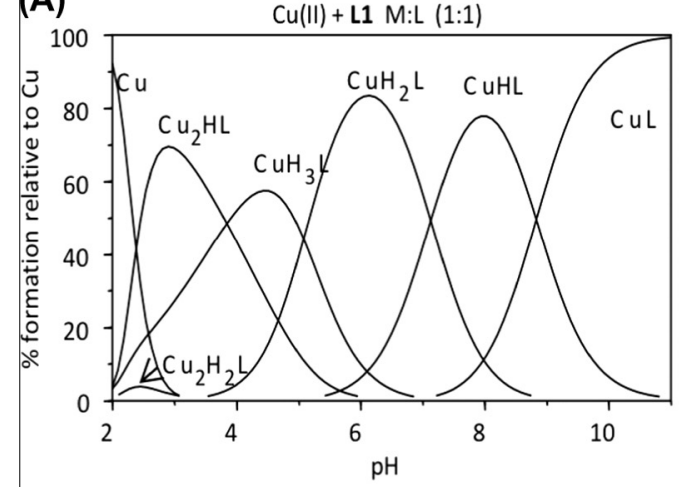

(C)

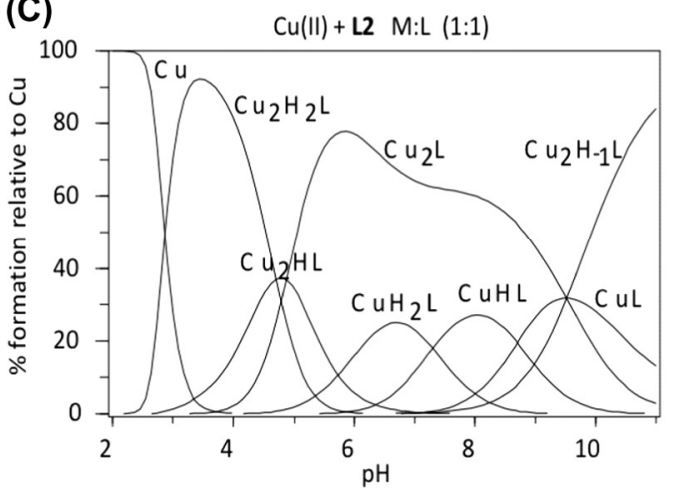

(B)

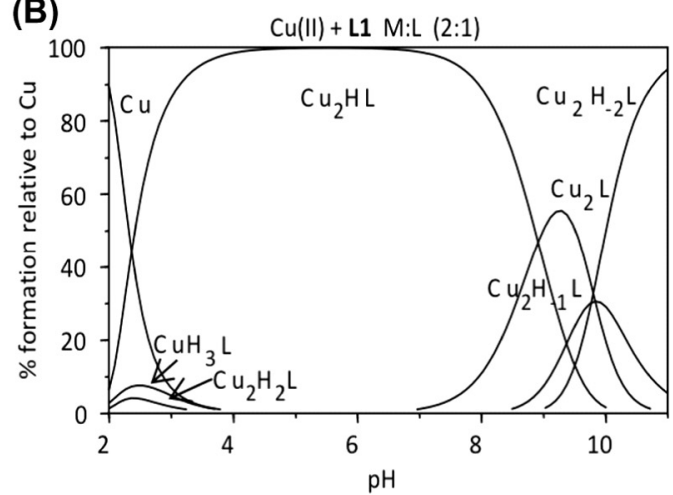

(D)

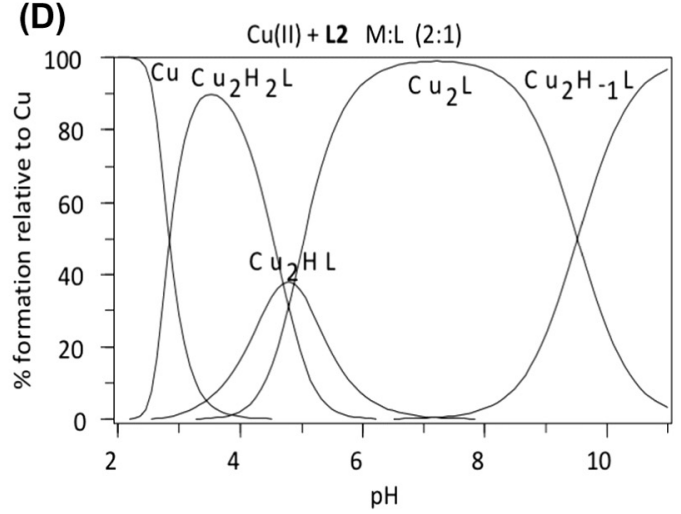

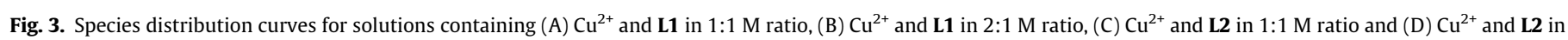
2:1 M ratio.

In order to explain these values it has to be assumed that, as already discussed in our previous report [3], the entry of the second copper in $\mathbf{L 1}$ is accompanied by the cleavage of some of the coordinative bonds between the metal ligand followed by reorganization of the macrocycle to give an evenly distributed 4-coordination of the metal centers in the binuclear complexes. However it 

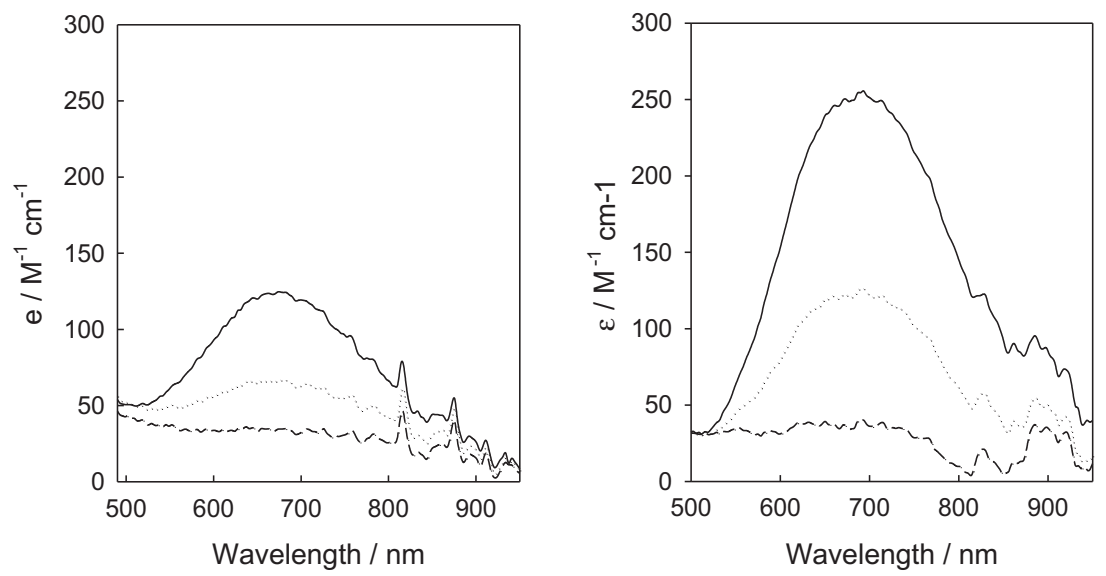

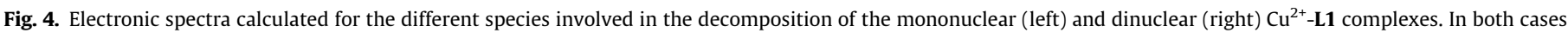
the continuous line corresponds to the starting complex, the dotted line to the intermediate and the dashed line to the final decomposition product.

seems that for $\mathbf{L} \mathbf{2}$ the coordination numbers of the metal centers in the mono-and binuclear should be similar with a coordination number of four. In this case, bond breaking followed by bond reorganization upon the entry of the second metal ion would not be necessary.

\subsection{The kinetics of the acid-promoted decomposition of mono- and binuclear $\mathrm{Cu}^{2+}-\mathbf{L 1}$ and $\mathbf{C u}-\mathbf{L} \mathbf{2}$ complexes}

According to the species distribution curves in Fig. 3, addition of an excess of acid to a solution containing $\mathrm{Cu}^{2+}-\mathbf{L 1}$ or $\mathrm{Cu}^{2+}-\mathbf{L} \mathbf{2}$ Complexes leads to complex decomposition with formation of $\mathrm{Cu}^{2+}$ and $\mathrm{H}_{6} \mathbf{L 1}^{6+}$ or $\mathrm{H}_{8} \mathbf{L} 2^{8+}$ respectively, and the kinetics of decomposition can be easily followed by measuring the disappearance of the characteristic absorption band of the complex. Nevertheless, to avoid possible complications caused by different species having different kinetics of decomposition, the composition of the starting solution was selected with the help of the speciation curves in such a way that there is a single major species in solution. Thus, for the $\mathrm{Cu}^{2+}-\mathbf{L 1}$ system the kinetics of decomposition was monitored for solutions containing the mononuclear $\mathrm{Cu}\left(\mathrm{H}_{2} \mathbf{L 1}\right)^{4+}, \mathrm{Cu}(\mathrm{HL1})^{3+}$ and $\mathrm{CuL1}^{2+}$, and the binuclear $\mathrm{Cu}_{2}(\mathrm{HL1})^{5+}$ species. For $\mathrm{Cu}^{2+}-\mathbf{L 2}$ the selected species were only binuclear $\left(\mathrm{Cu}_{2}\left(\mathrm{H}_{2} \mathbf{L} 2\right)^{6+}, \mathrm{Cu}_{2} \mathbf{L} 2^{4+}\right.$ and $\mathrm{Cu}_{2-}$ L1 $(\mathrm{OH})^{3+}$ ) because the species distribution curves (Fig. $3 \mathrm{C}$ and $\mathrm{D}$ ) show that significant amount of binuclear species are present even in $1: 1 \mathrm{M}$ ratio.

For the $\mathrm{Cu}^{2+}-\mathbf{L 1}$ system all the three mononuclear species studied show an absorption band at $660 \mathrm{~nm}$ whose intensity decreases within the stopped-flow mixing time upon addition of the acid excess. This initial rapid step leads to an intermediate with a broad band at approximately the same wavelength, and the values of the rate constant $\left(k_{1 \text { obs }}\right)$ cannot be measured even at the lower concentrations of acid compatible with pseudo-first order conditions. Following that step there are additional spectral changes that occur in the stopped-flow time scale and that can be fitted satisfactorily by using a kinetic model with two consecutive exponentials to yield the spectra of the different participating species (Fig. 4) and the rate constants for both steps ( $k_{2 \text { obs }}$ and $k_{3 \text { obs }}$ ). The values of the latter rate constants show a linear dependence on the acid concentration (Fig. 5) and they are similar for the three $\mathrm{Cu}\left(\mathrm{H}_{x} \mathbf{L 1}\right)^{(2+x)+}$ $(x=0-2)$ species, so that they can be satisfactorily fitted by eq. 1 and yield the values of $a$ and $b$ in Table 3. Although the binuclear $\mathrm{Cu}_{2}(\mathrm{HL1})^{5+}$ species show the absorption band slightly shifted $(685 \mathrm{~nm})$ with respect to the mononuclear complexes, the kinetic

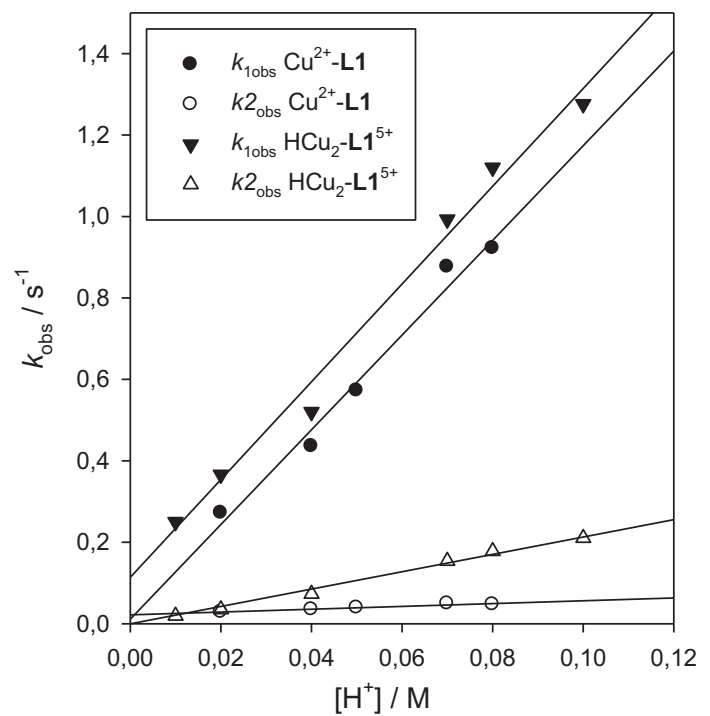

Fig. 5. Plot of the acid dependence of the rate constants for the two resolved kinetic steps in the decomposition of mono- and di-nuclear $\mathrm{Cu}^{2+}-\mathbf{L 1}$ complexes $([\mathrm{NaCl}]=0.15 \mathrm{M}, 298.1 \mathrm{~K})$.

Table 3

Kinetics parameters for the decomposition of mono- and di-nuclear $\mathrm{Cu}^{2+}-\mathbf{L 1}$ complexes.

\begin{tabular}{lllc}
\hline Complex & Step & $a\left(\mathrm{~s}^{-1}\right)$ & $b\left(\mathrm{M}^{-1} \mathrm{~s}^{-1}\right)$ \\
\hline $\mathrm{Cu}\left(\mathrm{H}_{x} \mathbf{L 1}\right)^{2+}(x=0,1,2)$ & 2 & $(5 \pm 4) \times 10^{-2}$ & $(11.1 \pm 0.7)$ \\
$\mathrm{Cu}_{2}(\mathrm{HL1})^{5+}$ & 3 & $(2.0 \pm 0.2) \times 10^{-2}$ & $(3.8 \pm 0.4)$ \\
& 2 & $(1.1 \pm 0.4) \times 10^{-1}$ & $(12.0 \pm 0.06)$ \\
& 3 & 0 & $(2.13 \pm 0.05)$ \\
\hline
\end{tabular}

features are similar. There is a rapid-non-measurable kinetic step within the stopped-flow mixing time followed of two additional resolvable kinetic steps that depend on the acid concentration (see calculated spectra in Fig. 4 and rate constants in Fig. 5), the fit by Eq. (1) leading to the $a$ and $b$ values in Table 3.

$k=a+b \times\left[\mathrm{H}^{+}\right]$

The occurrence of polyphasic kinetics in the decomposition is not surprising given the polydentate nature of the ligand, and actually there are several literature precedents [39,40]. The 
intermediates detected in the decomposition of the mono- and dinuclear species must correspond to higher protonated forms of the complexes not detected in the potentiometric studies because of its transient nature. It is important to note that Fig. 4 shows that the molar absorptivies of the binuclear species essentially double those of the mononuclear species, which rules out the possibility that the first metal ion dissociates very rapidly. From the mechanistic point of view, the rate law in Eq. (1) can be easily interpreted in terms of the classical mechanism proposed by Margerum et al. (Eqs. 2-4) [41-43]. The first step (Eq. 2) involves the partial dissociation of one $\mathrm{Cu}-\mathrm{N}$ bond to yield an activated intermediate $\left[\mathrm{Cu}\left(\mathrm{H}_{x} \mathrm{Cu}\right)^{(2+x)+}\right]^{*}$ that can decompose through two parallel pathways, one of them involving solvent attack (Eq. 3) and the other one involving proton attack (Eq. 4). If the activated intermediate is assumed to be formed under steady-state conditions, the rate law for this mechanism is given by Eq. (5), which simplifies to the form of Eq. (1) when the $k_{\mathrm{H}}\left[\mathrm{H}^{+}\right]$in the denominator is negligible. In that case, the non-zero intercept and the slope in the plot measure the relative contributions of the solvent and proton attacks. The small values of $a$ in Table 3 would thus indicate that the complexes decompose mainly through proton attack to the activated intermediate.

$$
\begin{aligned}
& \mathrm{Cu}\left(\mathrm{H}_{\mathrm{x}} \mathrm{L}\right)^{(2+\mathrm{x})+} \leftrightarrows\left[\mathrm{Cu}\left(\mathrm{H}_{x} \mathrm{~L}\right)^{(2+x)+}\right]^{*} k_{\text {act }}, k_{\text {-act }} \\
& {\left[\mathrm{Cu}\left(\mathrm{H}_{x} \mathrm{~L}\right)^{(2+x)+}\right]^{*}+\mathrm{H}_{2} \mathrm{O} \rightarrow \mathrm{Cu}^{2+}+\left(\mathrm{H}_{x} \mathrm{~L}\right)^{x+} k_{\mathrm{H}_{2} \mathrm{O}}} \\
& {\left[\mathrm{Cu}\left(\mathrm{H}_{x} \mathrm{~L}\right)^{(2+x)+}\right]^{*}+\mathrm{H}^{+} \rightarrow \mathrm{Cu}^{2+}+\left(\mathrm{H}_{x} \mathrm{~L}\right)^{x+} k_{\mathrm{H}}} \\
& k_{\mathrm{obs}}=\frac{k_{\text {act }} k_{\mathrm{H}_{2} \mathrm{O}}+k_{\mathrm{act}} k_{\mathrm{H}}\left[\mathrm{H}^{+}\right]}{k_{\text {-act }}+k_{\mathrm{H}_{2} \mathrm{O}}+k_{\mathrm{H}}\left[\mathrm{H}^{+}\right]}
\end{aligned}
$$

Another interesting aspect of the kinetic data in Fig. 5 is that the $k_{\text {2obs }}$ values for decomposition of the mono- and dinuclear complexes are very similar, whereas the spectra in Fig. 4 indicate that the molar absorptivities of the binuclear species double the values for the mononuclear species. These facts can be considered strong evidence on the operation of statistical kinetics in the decomposition of the dinuclear complexes, a phenomenon previously reported for other macrocyclic complexes and clusters [44-47]. In that case the dinuclear complex will decompose in two steps which involve the sequential dissociation of both $\mathrm{Cu}^{2+}$ ions with rate constants in the statistical 2:1 ratio, but because of mathematical simplifications only the value of the rate constant for the exit of the second $\mathrm{Cu}^{2+}$ can be measured and so, the values are similar to those found for the decomposition of the mononuclear complex. The conditions required for this mathematical simplification have been summarized recently and essentially consist in the independent behavior of the metal centres in the binuclear species both from the kinetic and spectral points of view [45].

In the case of $\mathbf{L} \mathbf{2}$ the situation is different. As noted above, only the decomposition of binuclear $\mathrm{Cu}_{2}\left(\mathrm{H}_{2} \mathbf{L} 2\right)^{6+}, \mathrm{Cu}_{2} \mathbf{L 2}^{4+}$ and $\mathrm{Cu}_{2-}$ $\mathbf{L 1}(\mathbf{O H})^{3+}$ complexes were studied, although similar kinetics was found for all of them. The binuclear species show spectra with two overlapping bands, one centered at $635 \mathrm{~nm}$, typical of species with $s p$ geometry, and the other one centered at $780 \mathrm{~nm}$, typical for complexes with $t b p$ geometry. In this case there are not significant spectral changes within the stopped-flow mixing time when an excess of acid is added, and the spectral changes recorded during the decomposition process indicate biphasic kinetics with the band centered at $780 \mathrm{~nm}$ disappearing faster than that at $660 \mathrm{~nm}$ (Fig. 6). The changes were fitted to a model with two consecutive steps that yields the values of the two rate constants and the calculated spectra in Fig. 7. The acid dependence of the rate constant for the first step (Fig. 8) can be represented by Eq. (6) with $c=(0.90 \pm 0.03) \mathrm{s}^{-1}$ and $d=(41 \pm 3) \mathrm{M}^{-1}$, while the second step shows a linear dependence with acid concentration (Eq. 1, Fig. 8) with $b=(4.3 \pm 0.2) \mathrm{M}^{-1} \mathrm{~s}^{-1}$ and a negligible value of $a$. It is important to note that Eq. (6) is also a simplification of Eq. (5), so that the Margerum's mechanism can be also operating in this case, although the absence of a proton-independent term in the numerator would indicate that the contribution of the solvent attack pathway is negligible in this case.

$k=\frac{c d \times\left[\mathrm{H}^{+}\right]}{1+d \times\left[H^{+}\right]}$

The most important observation derived from the kinetics of decomposition of $\mathrm{Cu}^{2+}-\mathbf{L} \mathbf{2}$ complexes is that the starting complex appears to contain the metal centres in two different geometries. One $\mathrm{Cu}^{2+}$ would have a tbp environment and it is the first one to be released (Eq. 7). The other $\mathrm{Cu}^{2+}$ would be in a square pyramidal $(s p)$ environment and would dissociate more slowly (Eq. 8). The dissociation of both ions would go through the Margerum's mechanism with a negligible contribution of the pathway involving solvent attack. The different equations required to fit kinetic data for both steps would simply reflect the different relative values of the intimate rate constants in Eq. (5).

$$
\begin{aligned}
& \mathrm{Cu}_{s p} \mathrm{Cu}_{t b p} \mathbf{L} \mathbf{2}+\mathrm{H}^{+} \rightarrow \mathrm{Cu}_{s p} \mathbf{L} \mathbf{2}+\mathrm{Cu}^{2+} \\
& \mathrm{Cu}_{s p} \mathbf{L} \mathbf{2}+\mathrm{H}^{+} \rightarrow\left(\mathrm{H}_{x} \mathbf{L} \mathbf{2}\right)^{x+}+\mathrm{Cu}^{2+}
\end{aligned}
$$

\subsection{The kinetics of formation of mono- and binuclear $\mathrm{Cu}^{2+}-\mathbf{L 1}$ and $\mathrm{Cu}^{2+}-\mathbf{L 2}$ complexes}

The kinetics of complex formation has also been studied over the $\mathrm{pH}$ range 2.8-5.3. In order to make complex formation slow enough to be measured with the stopped-flow instrument, the kinetic studies were conducted under non-pseudo first-order conditions, i.e., using stoichiometric concentrations of the metal ion ( 1 or 2 equivalents) and the ligand. No buffers were used because the highly protonated form of the ligands can interact with the anionic form of the buffer as has been previously shown [24].

The formation of mononuclear $\mathrm{Cu}^{2+}-\mathbf{L 1}$ species was monitored using $\mathrm{Cu}^{2+}$ and $\mathbf{L 1}$ in ratios close to $1: 1$, and the spectral changes show the appearance of the absorption band typical of the $\left[\mathrm{Cu}\left(\mathrm{H}_{z-}\right.\right.$

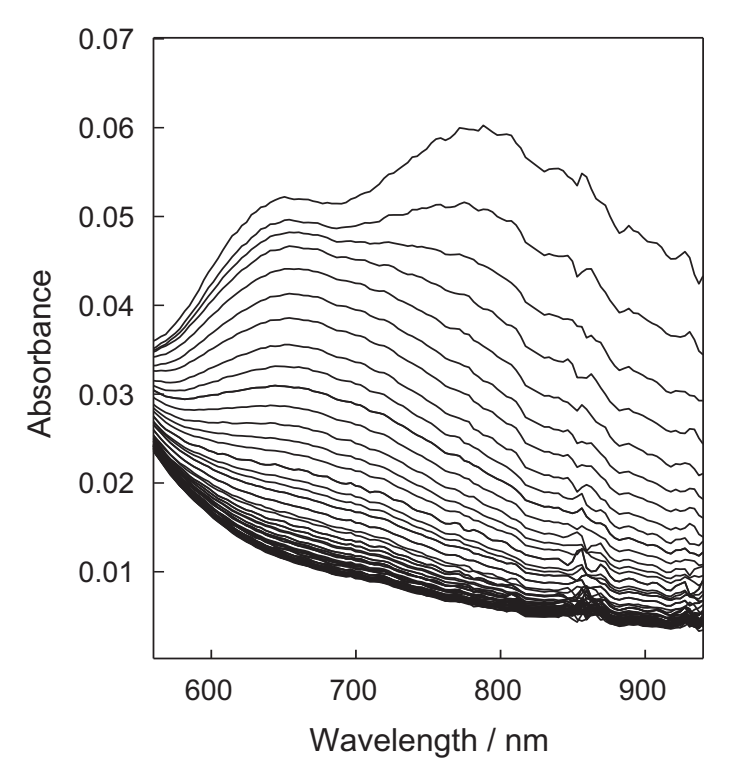

Fig. 6. Spectral changes with time for the reaction of the $\mathrm{Cu}_{2}\left(\mathrm{H}_{2} \mathbf{L 2}\right)^{6+}$ complex with acid $\left([\mathrm{NaCl}]=0.15 \mathrm{M}, 298.1 \mathrm{~K},\left[\mathrm{H}^{+}\right]=0.1 \mathrm{M}, 10^{3}\right.$ s logarithmic base $)$. 


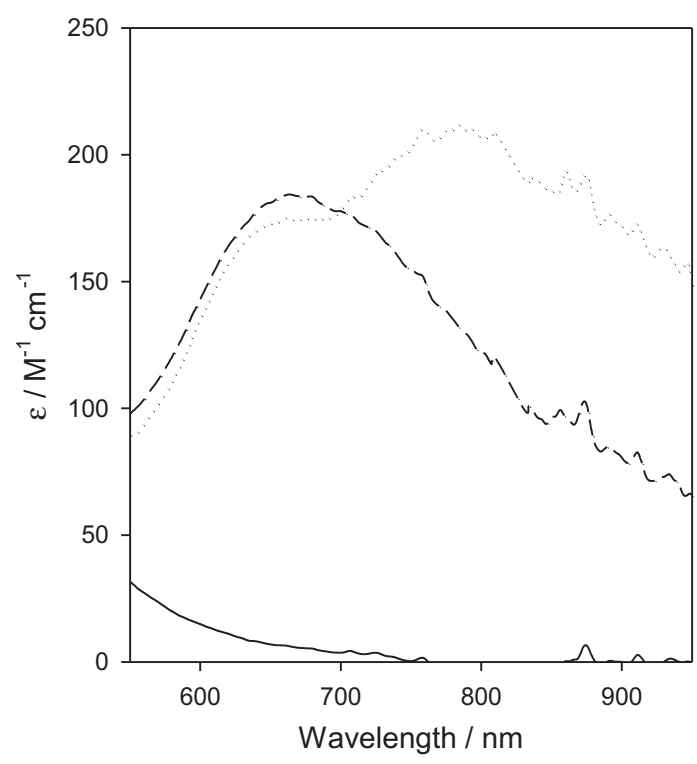

Fig. 7. Electronic spectra calculated from the kinetic data for the decomposition of binuclear $\mathrm{Cu}^{2+}-\mathbf{L} \mathbf{2}$ complexes. The spectra correspond to the starting complex (solid line), the reaction intermediate (dotted line) and the final reaction product (dashed line).

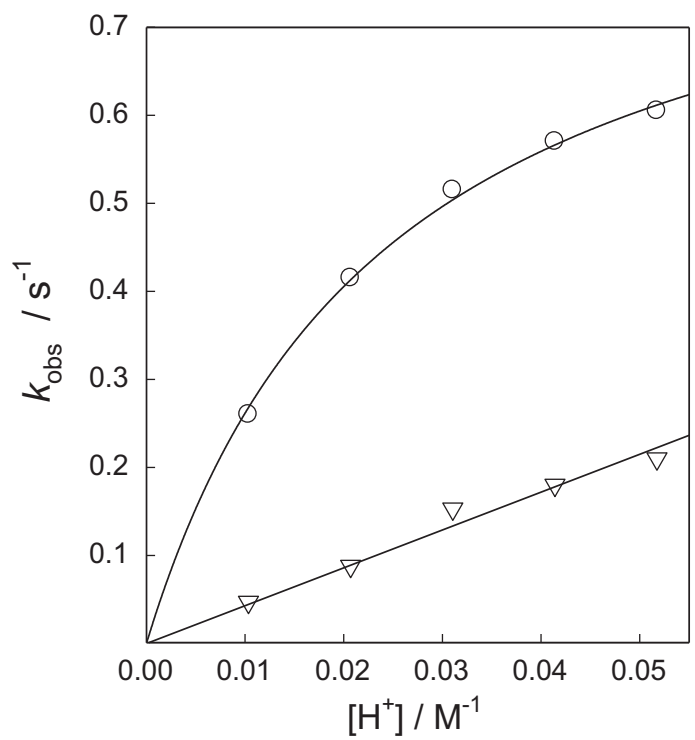

Fig. 8. Plot of the dependence on the acid concentration for the observed rate constant in the first (circles) and the second (triangles) kinetic step during the acidpromoted decomposition of the binuclear complexes with $\mathbf{L 2},([\mathrm{NaCl}]=0.15 \mathrm{M}$, $298.1 \mathrm{~K})$.

L1 $)^{(2+z)+}$ ] $(z=0-2)$ species centered at $665 \mathrm{~nm}$. According to the speciation curves and the experimental conditions used, that anticipate a $\mathrm{pH}$ decrease upon complex formation, the major species in the reaction product is $\mathrm{Cu}\left(\mathrm{H}_{2} \mathbf{L} \mathbf{1}\right)^{4+}$. Interestingly, the fit of these spectral changes also require a model with two consecutive steps and the spectra calculated for the different species (Fig. 9) agree very well with those derived from kinetic data for complex decomposition (compare with Fig. 4), thus indicating that formation and decomposition of these complexes occurs through the same reaction intermediate. As indicated above, this intermediate probably corresponds to a highly protonated species that is not detected in the potentiometric studies because of its transient nature. With regard to the rate constants, $k_{1 \text { obs }}$ is first order with respect to both reagents $\left(\mathrm{Cu}^{2+}\right.$ and $\left.\mathbf{L 1}\right)$, whereas $k_{2 \text { obs }}$ corresponds to a reorganization step with first order kinetics (Eqs. 9 and 10). However, both rate constants depend on the acid concentration, as illustrated in Fig. 10 for the first step. This dependence is typical of prequilibria involving at least one of the reagents. As there is no formation of $\mathrm{Cu}^{2+}$ hydroxocomplexes in the $\mathrm{pH}$ range covered in these kinetic studies, the dependence must be associated exclusively to the different protonated forms of the ligand. According to the species distribution curves, the solutions may contain $\mathrm{H}_{4} \mathbf{L 1}^{4+}, \mathrm{H}_{5} \mathbf{L 1}^{5+}$ and $\mathrm{H}_{6} \mathbf{L 1}^{6+}$, and complex formation can then occur through three parallel pathways involving $\mathrm{Cu}^{2+}$ and these ligand forms (Eqs. 11-15). The rate law for this mechanism (Eq. 16) contains too many unknowns but the $\mathrm{pH}$ dependence of the experimental rate constant can be used to separate the contribution of the different $\mathrm{H}_{\mathrm{x}} \mathbf{L 1}^{\mathrm{x}}$ species following a procedure previously used for a similar case [48]. If the values of the equilibrium constants for ligand protonation are fixed to the potentiometric values, Eq. (16) can be rearranged by calculating the values of the product $k_{\mathrm{obs}} D$ with $D=1+K_{\text {eq } 5}\left[\mathrm{H}^{+}\right]+K_{\text {eq } 5} K_{\text {eq } 6}\left[\mathrm{H}^{+}\right]^{2}$, and a plot of the $k_{1 \mathrm{obs}} D$ values against $\left[\mathrm{H}^{+}\right]$should provide information about the relative contributions of the different protonated forms of the ligand. Such a plot is included in Fig. 11, and a fit of the data indicates that only $\mathrm{H}_{6} \mathbf{L 1}^{6+}$ contributes significantly to complex formation under the experimental conditions used, with a value of $k_{6}=(1.62 \pm 0.02) \times 10^{3}$ $\mathrm{M}^{-1} \mathrm{~s}^{-1}$. Although the values of $k_{4}$ and $k_{5}$ should be expected to be higher than $k_{6}$ for electrostatic reasons, the difference must not be too large because the experimental results indicate that they are not able to compensate the larger concentration of $\mathrm{H}_{6} \mathbf{L 1}^{6+}$, the dominant species at those conditions (Fig. 1). Moreover, we have also shown recently that the changes in the network of hydrogen bonds existing between different protonated forms of polydentate ligands can even make slower the reaction through the less protonated forms [49].

$$
\begin{aligned}
& \mathrm{Cu}^{2+}+\left(\mathrm{H}_{x} \mathbf{L 1}\right)^{x+} \rightarrow\left[\mathrm{Cu}\left(\mathrm{H}_{y} \mathbf{L 1}\right)^{(2+y)+}\right]+(x-y) \mathrm{H}^{+} k_{1 \mathrm{obs}} \\
& {\left[\mathrm{Cu}\left(\mathrm{H}_{y} \mathbf{L 1}\right)^{(2+y)+}\right] \rightarrow\left[\mathrm{Cu}\left(\mathrm{H}_{z} \mathbf{L 1}\right)^{(2+z)+}\right]+(y-z) \mathrm{H}^{+} k_{2 \mathrm{obs}}} \\
& \left(\mathrm{H}_{4} \mathbf{L} \mathbf{1}\right)^{4+}+\mathrm{H}^{+} \leftrightarrows\left(\mathrm{H}_{5} \mathbf{L} \mathbf{1}\right)^{5+} ; K_{\mathrm{eq} 5} \\
& \left(\mathrm{H}_{5} \mathbf{L 1}\right)^{5+}+\mathrm{H}^{+} \leftrightarrows\left(\mathrm{H}_{6} \mathbf{L} \mathbf{1}\right)^{6+} ; K_{\mathrm{eq} 6} \\
& \left(\mathrm{H}_{4} \mathbf{L 1}\right)^{4+}+\mathrm{Cu}^{2+} \rightarrow \mathrm{Cu}\left(\mathrm{H}_{\mathrm{X}} \mathbf{L 1}\right)^{(2+\mathrm{X})+}+\mathrm{H}^{+} ; k_{4} \\
& \left(\mathrm{H}_{5} \mathbf{L 1}\right)^{5+}+\mathrm{Cu}^{2+} \rightarrow \mathrm{Cu}\left(\mathrm{H}_{\mathrm{X}} \mathbf{L 1}\right)^{(2+\mathrm{X})+}+\mathrm{H}^{+} ; k_{5} \\
& \left(\mathrm{H}_{6} \mathbf{L 1}\right)^{6+}+\mathrm{Cu}^{2+} \rightarrow \mathrm{Cu}\left(\mathrm{H}_{\mathrm{X}} \mathbf{L 1}\right)^{(2+\mathrm{X})+}+\mathrm{H}^{+} ; k_{6} \\
& k_{\mathrm{obs}}=\frac{k_{4}+K_{\mathrm{eq} 5} k_{5}\left[\mathrm{H}^{+}\right]+K_{\mathrm{eq} 5} K_{\mathrm{eq} 6} k_{6}\left[H^{+}\right]^{2}}{1+K_{\mathrm{eq} 5}\left[H^{+}\right]+K_{\mathrm{eq} 5} K_{\mathrm{eq} 6}\left[H^{+}\right]^{2}}
\end{aligned}
$$

To monitor the formation of binuclear $\mathrm{Cu}^{2+}-\mathbf{L 1}$ complexes, solutions of $\mathrm{Cu}^{2+}$ and the ligand in $2: 1 \mathrm{M}$ ratio were mixed in the stopped-flow instrument. The $\mathrm{pH}$ range covered was similar to that used for mononuclear species and, according to the species distribution curves, the reaction product will be a mixture of $\mathrm{Cu}\left(\mathrm{H}_{2} \mathrm{~L} 1\right)^{4+}$, $\mathrm{Cu}_{2}(\mathrm{HL} 1)^{5+}$ and $\mathrm{Cu}_{2}\left(\mathrm{H}_{2} \mathrm{~L} 1\right)^{6+}$. The analysis of the kinetic data now requires a model with three consecutive steps, the calculated spectra being those shown in Fig. 9. The first step leads to formation of the same intermediate observed during the formation of the mononuclear species (compare spectra for the formation of mono and dinuclear species in Fig. 9), and the rate constants are also similar (Figs. 10 and 11), the value of $k_{6}$ derived using the numerical treatment described above being $k_{6}=(1.82 \pm 0.01) \times 10^{3} \mathrm{M}^{-1} \mathrm{~s}^{-1}$. In 

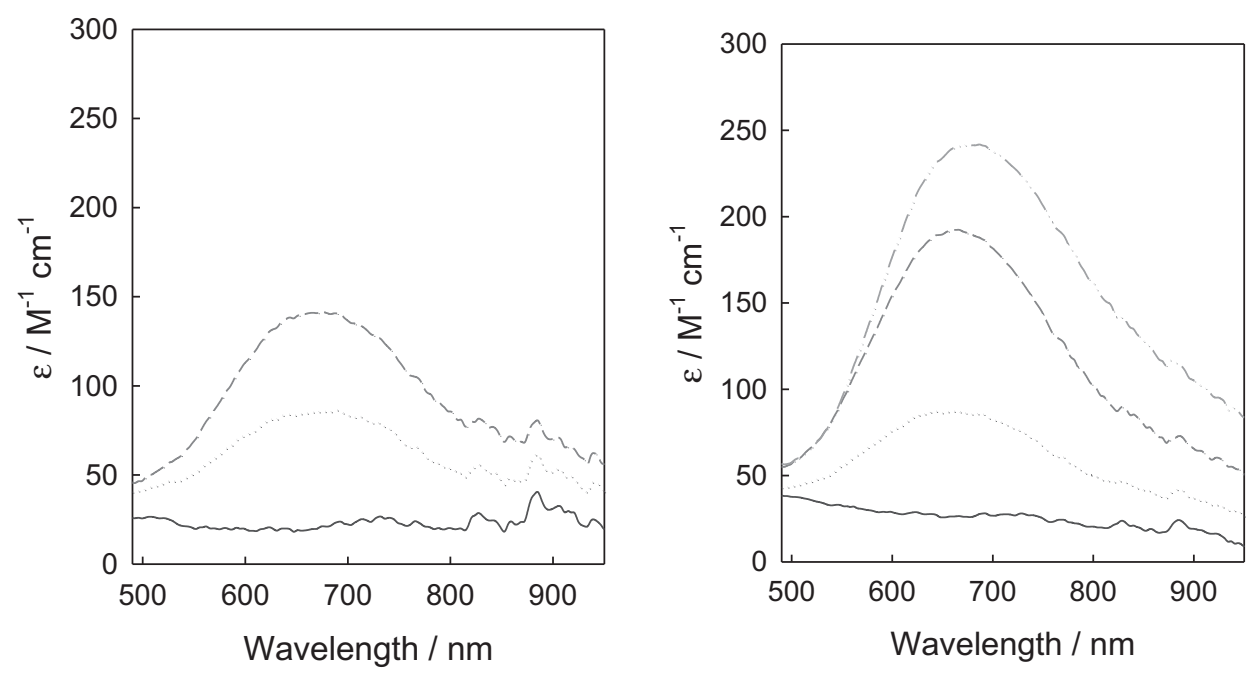

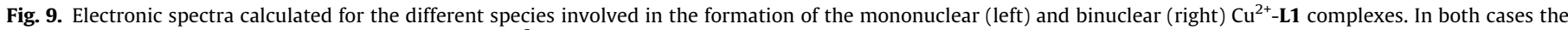
continuous line corresponds to the starting complex $\left(\mathrm{Cu}^{2+}\right)$, the dotted line to the intermediate and the dashed line to the final complex.

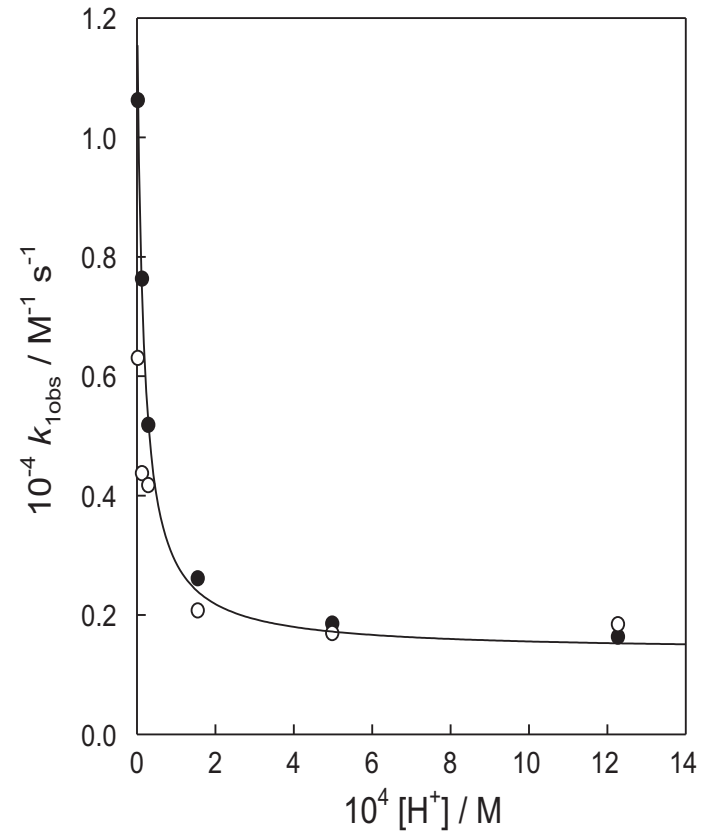

Fig. 10. Plot of the dependence on the acid concentration of the observed rate constants for the first kinetic step in the formation process of mono- (filled circles) and binuclear (empty circles) $\mathrm{Cu}^{2+}$ complexes with $\mathbf{L 1}([\mathrm{NaCl}]=0.15 \mathrm{M}, 298.1 \mathrm{~K})$.

fact, satisfactory results are obtained when the analysis of both series of experiment is carried out simultaneously with a value of $k_{6}=(1.72 \pm 0.03) \times 10^{3} \mathrm{M}^{-1} \mathrm{~s}^{-1}$.

The second resolved step in the formation of binuclear species leads to an intermediate whose spectrum clearly indicates that it corresponds to a binuclear complex (see Fig. 9), i.e. coordination of the second metal ion occurs in this step. However, attempts to fit the data using a second order kinetics for this step were unsuccessful and satisfactory fits lead to first order rate constants $k_{2 \text { obs }}$ that shows a $\mathrm{pH}$ dependence that reveals the existence of an acid-base pre-equilibrium also in this step, as found for the case of mononuclear species. Unfortunately, the absence of reliable equilibrium constants hinders an analysis similar to that carried out for the first kinetic step. Moreover, it appears that the coordination of the second metal ion and the reorganization of the first

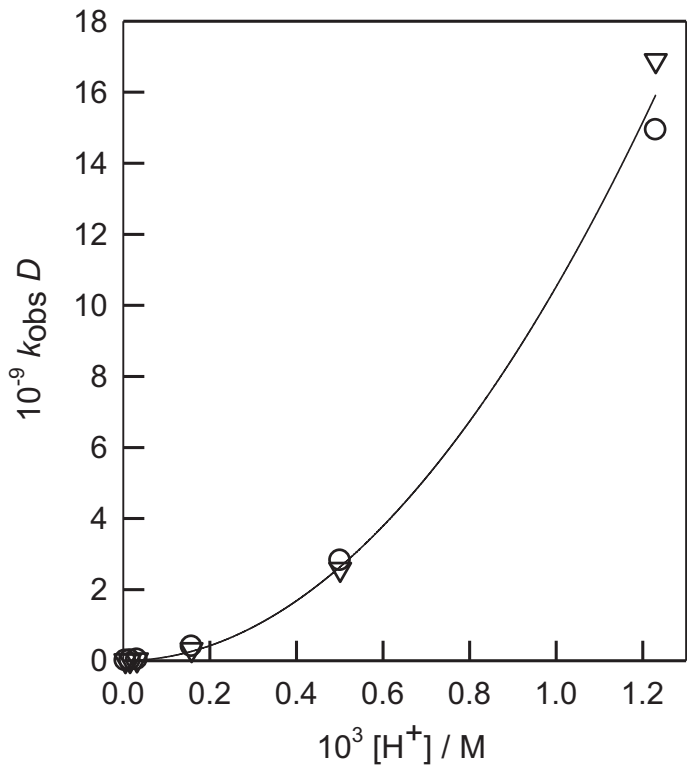

Fig. 11. Plot of the dependence on the acid concentration of the product $k_{1 \text { obs }} D$, with $D=1+K_{\text {eq5 }}\left[\mathrm{H}^{+}\right]+K_{\text {eq5 }} K_{\text {eq } 6}\left[\mathrm{H}^{+}\right]^{2}$. The triangles and the circles correspond to data for experiments leading to the formation of mono- and binuclear complexes, respectively.

one occur with close rates and this hinders a satisfactory analysis of the kinetic data for this step. The third step corresponds to reorganization of the binuclear species and it takes place with a rate constant independent on the acid concentration, $k_{3}$. $=(8 \pm 1) \times 10^{-3} \mathrm{~s}^{-1}$. The final spectrum shows an absorption band centered at $685 \mathrm{~nm}$, in good agreement with the spectrum recorded for $\mathrm{Cu}_{2}(\mathrm{HL1})^{5+}$.

The kinetics of complex formation between $\mathrm{Cu}^{2+}$ and $\mathbf{L 2}$ has been also studied, although limited in this case to the binuclear species because the species distribution curves indicate that significant amounts of binuclear species are formed even in 1:1 M ratio. The spectral changes recorded during complex formation (Fig. 12) show the appearance of two overlapping bands with maxima at c.a. 760 and $635 \mathrm{~nm}$. However, the $635 \mathrm{~nm}$ band appears faster than the $760 \mathrm{~nm}$ band, so that a kinetic model with two consecutive steps was used to fit the data. As both steps can correspond to 


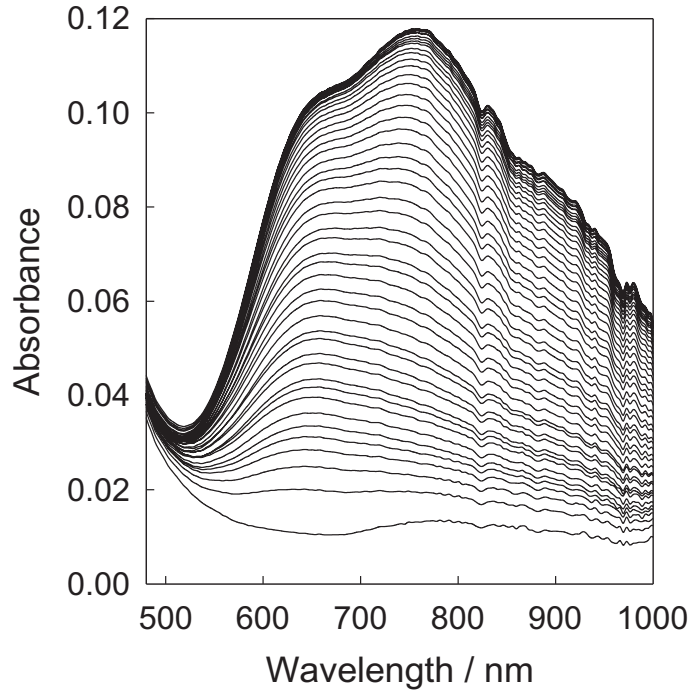

Fig. 12. Typical spectral changes recorded during formation of binuclear $\mathrm{Cu}^{2+}-\mathbf{L 2}$ complexes showing the successive appearance of the two absorption bands.

the sequential coordination of the two $\mathrm{Cu}^{2+}$ ions, a model with two consecutive second order processes was initially tested. However, it leads to unsatisfactory results and a model including consecutive second and first order processes was required for a satisfactory fit of the data. This conclusion was confirmed by kinetic experiments at different concentrations of the reagents, which showed that the half-time of the first step changes with the concentration whereas that of the second step does not change. The spectra calculated with this model are included in Fig. 13, which indicates that complex formation and decomposition also occur in this case through a common reaction intermediate. That intermediate is formed in the first step and leads to the development of the $635 \mathrm{~nm}$ band, typical of square pyramidal complexes, with a second order rate constant of $k_{1}=(4.59 \pm 0.04) \times 10^{2} \mathrm{M}^{-1} \mathrm{~s}^{-1}$. The second step leads to the appearance of the band at $760 \mathrm{~nm}$ and occurs with a first order rate constant of $k_{2}=(5.1 \pm 0.6) \times 10^{-2} \mathrm{~s}^{-1}$.

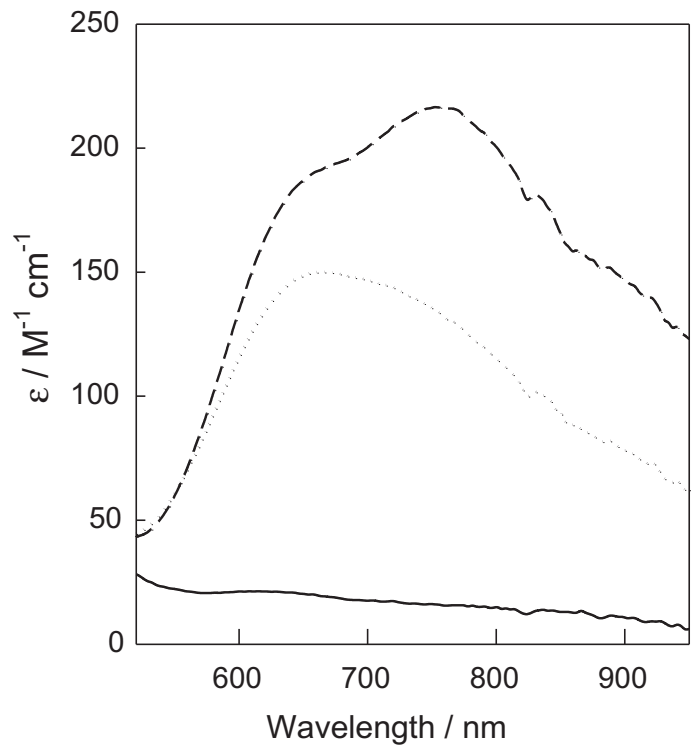

Fig. 13. Electronic spectra calculated for the starting complex (solid line), intermediate (dotted line) and the final product (dashed line) involved in the formation of binuclear $\mathrm{Cu}^{2+}-\mathbf{L} 2$ complexes.

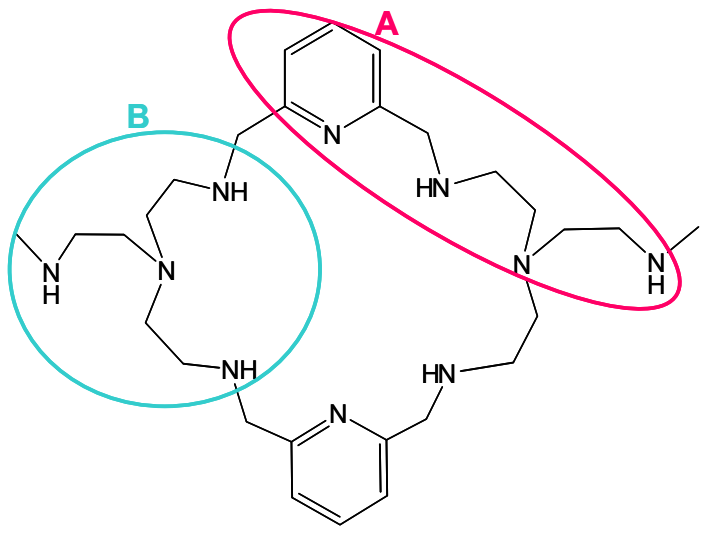

Fig. 14. Possible coordination modes of $\mathrm{Cu}^{2+}$ in $\mathrm{Cu}^{2+}$-L complexes.

Thus, it appears that $\mathbf{L} 2$ can accommodate $\mathrm{Cu}^{2+}$ ions in two different coordination environments: square pyramidal and trigonal bipyramidal. When the ions go into the macrocycle, the first one adopts $s p$ coordination and the second one tbp coordination. In contrast, when they leave the receptor, the $\mathrm{Cu}^{2+}$ with $t b p$ coordination is released first. Different models can be invoked to interpret these results, but the simplest one is to consider that each resolved kinetic step corresponds to the sequential coordination of one metal ion (Eqs. 17 and 18). Although the first-order kinetics in the second step is unusual, the fact that there is a common reaction intermediate in the processes of complex formation and decomposition supports this interpretation because decomposition of the binuclear species is reasonably expected to go through a mononuclear species.

$\mathrm{Cu}^{2+}+\mathrm{L} \rightarrow \mathrm{Cu}_{s p} \mathbf{L} 2 ; k_{1}$

$\mathrm{Cu}^{2+}+\mathrm{Cu}_{s p} \mathbf{L} \mathbf{2} \rightarrow\left(\mathrm{Cu}_{s p} \mathrm{Cu}_{t b p} \mathbf{L} \mathbf{2}\right) ; k_{2}$

\subsection{DFT study}

In previous papers we have found that the combination of theoretical studies with experimental information is very useful to understand structural reorganizations between $s p$ and $t b p$ geometries in macrocyclic copper complexes [30,49-51]. For that reason, and despite the very complex nature of the present systems hinders a detailed theoretical study, we decided to carry out some

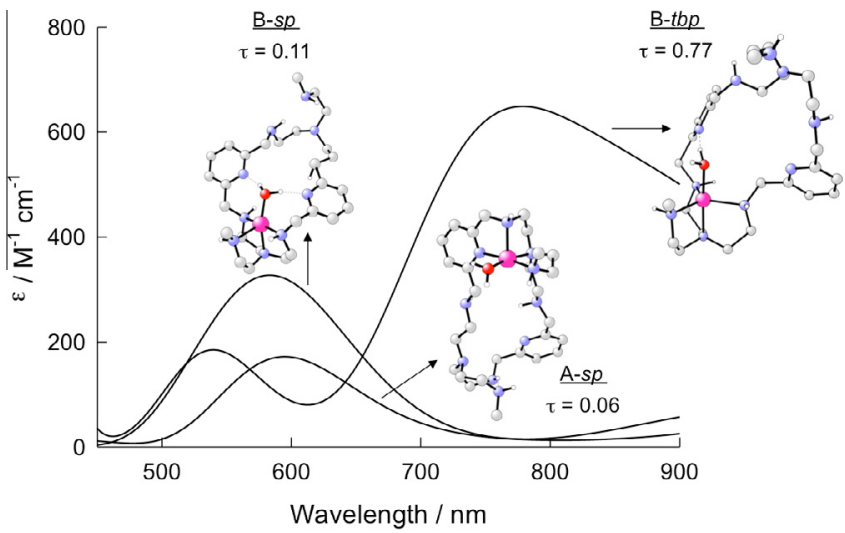

Fig. 15. Computed geometries, $\tau$ parameters, and corresponding TD-DFT calculated spectra obtained for mononuclear $\mathrm{Cu}\left(\mathrm{H}_{2} \mathrm{O}\right) \mathrm{L}^{2+}$ species. Hydrogen atoms attached to carbon atoms have been omitted for clarity. Color code: N (blue); C (grey); O (red); $\mathrm{Cu}$ (pink); $\mathrm{H}$ (white). (For interpretation of the references to colour in this figure legend, the reader is referred to the web version of this article.) 

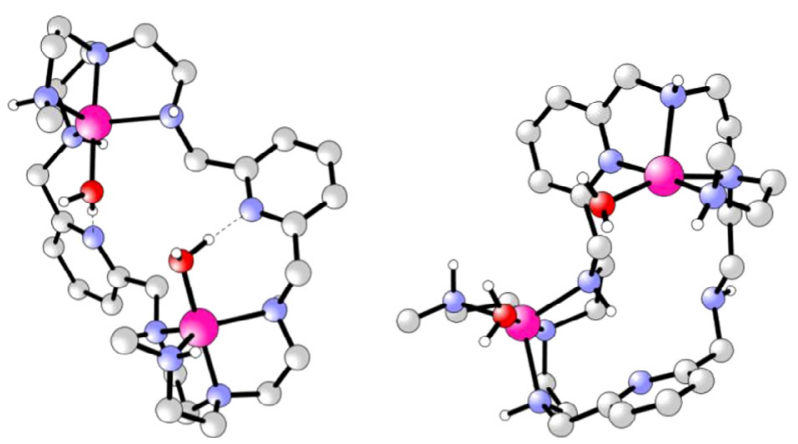

$$
\begin{gathered}
\mathrm{B}_{\mathrm{tpb}}-\mathrm{B}_{\mathrm{tbp}} \\
\tau=0.87,0.87 \\
\lambda_{\max }=490,620 \mathrm{~nm}
\end{gathered}
$$

$$
\begin{gathered}
\mathrm{A}_{\mathrm{sp}}-\mathrm{B}_{\mathrm{tpb}} \\
\tau=0.79,0.27 \\
\lambda_{\max }=630 \mathrm{~nm}
\end{gathered}
$$

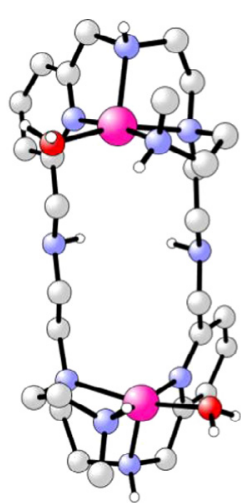

$$
\begin{gathered}
\mathrm{A}_{\mathrm{sp}}-\mathrm{A}_{\mathrm{sp}} \\
\tau=0.15,0.15 \\
\lambda_{\max }=610 \mathrm{~nm}
\end{gathered}
$$

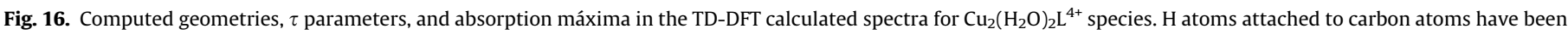

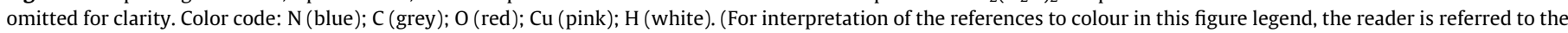
web version of this article.)

DFT and TD-DFT calculations aimed to analyze the possible coordination modes of $\mathrm{Cu}^{2+}$ coordinated to $\mathbf{L 1}$ and $\mathbf{L 2}$, as well as obtaining the corresponding calculated spectra in order to compare them with the experimental results. To simplify the calculations, and considering that previous work $[30,50]$ indicated that the external aromatic rings in these species do not participate in the coordination to copper centers, those aromatic rings were substituted in the model system by methyl groups to avoid conformational issues and reduce computational time. Initially, the efforts were focused on the location of all the different coordination modes that the methylated generic ligand $\mathrm{L}$ offers to one $\mathrm{Cu}^{2+}$ ion. A large number of optimizations where different combinations of the ligand donors of $L$ where initially situated in the proximities of the metal centre led only to two possible coordination modes, labeled as A and B in Fig. 14, with L acting as tetradentate in both of them. Mode A involves coordination to the nitrogen atom of one pyridine unit and three of the four nitrogen atoms of a close tren subunit, whereas mode $B$ involves the exclusive coordination to one of the tren subunits. For coordination mode B, two geometries close in energy were optimized, one of them showing the metal centre with $t b p$ coordination (B-tbp) and the other with $s p$ coordination (B-sp). This finding is in agreement with previous reports showing that tren-based $\mathrm{Cu}^{2+}$ complexes can adopt both geometries [30]. Importantly, in spite of the numerous attempts we could not locate any structure with $\mathrm{L}$ acting as pentadentate, probably because the remaining donors are located too far from the metal centre. Thus, an explicit $\mathrm{H}_{2} \mathrm{O}$ molecule was included in the calculations to complete the coordination environment of the metal centre. The optimized geometries for both models are shown in Fig. 15 together with their $\tau$ parameter [52], and TD-DFT calculated spectra [33]. It is important to note at this point that the limitations of the model, not considering for instance explicit solvent-solute interactions, prevent us from obtaining accurate relative energies, and instead we only observe a strong correlation with the number of intramolecular hydrogen bonds.

For the case of the mononuclear $\mathrm{Cu}^{2+}-\mathbf{L 1}$ complexes, the experimental spectra are close to those calculated for A-sp and B-sp, which indicates that they adopt $s p$ geometry. Although no experimental data are available for mononuclear $\mathrm{Cu}^{2+}-\mathbf{L 2}$ complexes, the intermediate formed upon coordination of the first ion during formation of the binuclear species also has a spectrum typical of $s p$ coordination. Theoretical studies were also conducted on the binuclear species and the most stable $\mathrm{Cu}_{2}\left(\mathrm{H}_{2} \mathrm{O}\right)_{2} \mathrm{~L}^{4+}$ calculated geometries are collected in Fig. 16. These result from the different possible combinations of two $\mathrm{Cu}^{2+}$ ions with A-sp and B-tbp geometries. Unfortunately, in this case comparison with the experimental spectra does not show clear correlations.

\section{Conclusion}

The kinetic data in the present work indicate that the previously detected structural reorganization of $\mathrm{Cu}^{2+}$ between different pentacoordinate geometries [30,49-51] are also possible with more complicated receptors. Moreover, the different behavior detected for the $\mathbf{L 1}$ and $\mathbf{L} 2$ ligands indicates that subtle changes in the nature of the ligand can lead to drastic changes in the chemical behavior. Thus, the chemistry of $\mathbf{L} \mathbf{1}$ complexes appears to be dominated by the $s p$ geometry, both in the mononuclear and the binuclear complexes, as well as in the intermediates detected during complex formation and decomposition. In contrast, $\mathrm{Cu}^{2+}-\mathbf{L 2}$ complexes can contain the metal ions in both coordination arrangements. Although the different behavior could be in principle associated to the presence of the quinoline ring, previous studies with $\mathbf{L 4}$ had shown [30] that the donor atom in the aromatic ring at the pendant arms cannot coordinate to the metal ion simultaneously to the nitrogens in the tren subunit. Moreover, theoretical calculations with the generic L ligand lacking of quinoline rings demonstrate that those additional nitrogen donors are not necessary to achieve both geometries, the experimental and theoretical spectra being in good agreement.

\section{Acknowledgements}

Financial support by the Spanish Ministerio de Ciencia e Innovación and FEDER funds of the E.U. (proyectos CSD2010-00065, CTQ2009-14443-C02-01 and CTQ2012-37821-C02-02) and from Generalitat Valenciana (PROMETEO2011/008) is gratefully acknowledged.

\section{Appendix A. Supplementary material}

Supplementary data associated with this article can be found, in the online version, at http://dx.doi.org/10.1016/j.ica.2013.12.020. 


\section{References}

[1] G.W. Gokel, Chem. Soc. Rev. 21 (1992) 39.

[2] G.W. Gokel, L.J. Barbour, S.L. De Wall, E.S. Meadows, Coord. Chem. Rev. 222 (2001) 127.

[3] M.P. Clares, J. Aguilar, R. Aucejo, C. Lodeiro, M.T. Albelda, F. Pina, J.C. Lima, A.J Parola, J. Pina, J. Seixas de Melo, C. Soriano, E. García-España, Inorg. Chem. 43 (2004) 6114.

[4] M.P. Clares, C. Lodeiro, D. Fernandez, A.J. Parola, F. Pina, E. García-España, C. Soriano, R. Tejero, Chem. Commun. (2006) 3824.

[5] J.H. Hartley, T.D. James, C.J. Ward, J. Chem. Soc., Perkin Trans. 1 (2000) 3155.

[6] G. Malojcic, I. Piantanida, M. Marinic, M. Zinic, M. Marjanovic, M. Kralj, K. Pavelic, H.-J. Schneider, Org. Biomol. Chem. 3 (2005) 4373.

[7] N. Lomadze, E. Gogritchiani, H.-J. Schneider, M.T. Albelda, J. Aguilar, E. GarcíaEspaña, S.V. Luis, Tetrahedron Lett. 43 (2002) 7801.

[8] T. Ikeda, K. Yoshida, H.-J. Schneider, J. Am. Chem. Soc. 117 (1995) 1453.

[9] M. Inclán, M.T. Albelda, J.C. Frías, S. Blasco, B. Verdejo, C. Serena, C. SalatCanela, M.L. Díaz, A. García-España, E. García-España, J. Am. Chem. Soc. 134 (2012) 9644.

[10] A. Fournet, J.C. Gantier, A. Gautheret, L. Leysalles, M.H. Munos, J. Mayrargue, H Moskowitz, A. Cavé, R. Hocquemiller, J. Antimicrob. Chemother. 33 (1994) 537.

[11] A.P. Gorka, A. de Dios, P.D. Roepe, J. Med. Chem. 56 (2013) 5231.

[12] P.G. Bray, S.A. Ward, P.M. ÓNeill, in: Malaria Drug, Diseases and Post-Genomic Biology, Springer-Verlag, CTMI 295, 2005, p. 3.

[13] J. Fiorito, F. Saeed, H. Zhang, A. Staniszewski, Y. Feng, Y.I. Francis, S. Rao, D.M. Thakkar, S.-X. Deng, D.W. Landry, O. Arancio, Eur. J. Med. Chem. 60 (2013) 285

[14] P.R. Graves, J.J. Kwiek, P. Fadden, R. Ray, K. Hardeman, A.M. Coley, M. Foley, T.A.J. Haystead, Mol. Pharmacol. 62 (2002) 1364.

[15] R.K. Arafa, G.H. Hegazy, G.A. Piazza, A.H. Abadi, Eur. J. Med. Chem. 63 (2013) 826.

[16] H.E. Gottlieb, V. Kotlyar, A. Nudelman, J. Org. Chem. 62 (1997) 7512.

[17] A.K. Covington, M. Paabo, R.A. Robinson, R.G. Bates, Anal. Chem. 40 (1968) 700

[18] G. Gran, Analyst 77 (1952) 661.

[19] F.J.C. Rossotti, H. Rossotti, J. Chem. Educ. 42 (1965) 375.

[20] M. Fontanelli, M. Micheloni, in: Proceedings of the 1st Spanish-Italian Congress on Thermodynamics of Metal Complexes, Diputación de Castellón, Spain, 1990.

[21] P. Gans, A. Sabatini, A. Vacca, Talanta 43 (1996) 1739.

[22] A. Sabatini, A. Vacca, P. Gans, Coord. Chem. Rev. 120 (1992) 389.

[23] R.A. Binstead, B. Jung, A.D. Zuberbühler, Spectrum Software Associates, Chappel Hill, 2000.

[24] M.G. Basallote, J. Durán, M.J. Fernández-Trujillo, M.A. Mañez, B. Szpoganicz, J. Chem. Soc., Dalton Trans. (1999) 1093.

[25] M.J. Frisch, G.W. Schlegel, H.B. Scuseria, G.E. Robb, M.A. Cheeseman, J.R. Scalmani, G. Barone, V. Mennucci, B. Petersson, G. A. Nakatsuji, H. Caricato, M Li, X. Hratchian, H.P. Izmaylov, A.F. Bloino, J. Zheng, G. Sonnenberg, J.L. Hada, M. Ehara, M. Toyota, K. Fukuda, R. Hasegawa, J. Ishida, M. Nakajima, T. Honda, Y. Kitao, O. Nakai, H. Vreven, T. Montgomery, Jr., J.A. Peralta, J.E. Ogliaro, F. Bearpark, M. Heyd, J.J. Brothers, E. Kudin, K.N. Staroverov, V.N. Kobayashi, R. Normand, J. Raghavachari, K. Rendell, A. Burant, J.C. Iyengar, S.S.; Tomasi, J. Cossi, M. Rega, N. Millam, N.J. Klene, M. Knox, J.E. Cross, J.B. Bakken, V. Adamo, C. Jaramillo, J. Gomperts, R. Stratmann, R.E. Yazyev, O. Austin, A.J. Cammi, R.
Pomelli, C. Ochterski, J. W. Martin, R.L. Morokuma, K. Zakrzewski, V.G. Voth, G.A. Salvador, P. Dannenberg, J.J. Dapprich, S. Daniels, A. D. Farkas, Ö. Foresman, J.B. Ortiz, J.V. Cioslowski, J. Fox, D. J., Gaussian 09, Revision A.02; Gaussian Inc: Wallingford, CT, 2009.

[26] A.D. Becke, J. Chem. Phys. 98 (1993) 5648.

[27] C.T. Lee, W.T. Yang, R.G. Parr, Phys. Rev. B 37 (1988) 785.

[28] D. Andrae, U. Haussermann, M. Dolg, H. Stoll, H. Preuss, Theor. Chim. Acta 77 (1990) 123.

[29] A. Schaefer, H. Horn, R. Ahlrichs, J. Chem. Phys. 97 (1992) 2571.

[30] A.G. Algarra, M.G. Basallote, C.E. Castillo, M.P. Clares, A. Ferrer, E. GarcíaEspaña, J.M. Llinares, M.A. Máñez, C. Soriano, Inorg. Chem. 48 (2009) 902.

[31] M. Cossi, N. Rega, G. Scalmani, V. Barone, J. Comput. Chem. 24 (2003) 669.

[32] S. Grimme, J. Antony, S. Ehrlich, H. Krieg, J. Chem. Phys. 132 (2010) 154104.

[33] M.E. Casida, C. Jamorski, K.C. Casida, D.R. Salahub, J. Chem. Phys. 108 (1998) 4439.

[34] N.M. O'Boyle, A.L. Tenderholt, K.M. Langner, J. Comput. Chem. 29 (2008) 839.

[35] J. Costa, R. Delgado, M.G.B. Drew, V. Felix, R.T. Henriques, J.C. Waerenborgh, J. Chem. Soc., Dalton Trans. (1999) 3253.

[36] J. Costa, R. Delgado, Inorg. Chem. 32 (1993) 5257.

[37] A. Bencini, A. Bianchi, E. García-España, M. Micheloni, J.A. Ramírez, Coord. Chem. Rev. 188 (1999) 97.

[38] Q. Lu, R.I. Carroll, J.H. Reibenspies, A.E. Martell, A. Clearfield, J. Mol. Struct. 470 (1998) 121.

[39] B. Verdejo, A. Ferrer, S. Blasco, C.E. Castillo, J. González, J. Latorre, M.A. Máñez, M.G. Basallote, C. Soriano, E. García-España, Inorg. Chem. 46 (2007) 5707.

[40] C.E. Castillo, J. González-García, J.M. Llinares, M.A. Máñez, H.R. Jimenez, E. García-España, M.G. Basallote, Dalton Trans. 42 (2013) 6131.

[41] D.W. Margerum, G.R. Cayley, D.C. Weatherburn, G.K. Pagenkopf, ACS Monography $\mathrm{N}^{\circ} 174,1,1978$.

[42] R.A. Read, D.W. Margerum, Inorg. Chem. 20 (1981) 3143.

[43] L.H. Chen, C.S. Chung, Inorg. Chem. 28 (1989) 1402.

[44] M.G. Basallote, J. Durán, M.J. Fernández-Trujillo, M.A. Máñez, J. Chem. Soc., Dalton Trans. (1999) 3817.

[45] A.G. Algarra, M.J. Fernández-Trujillo, M.G. Basallote, Chem. Eur. J. 18 (2012) 5036.

[46] A.G. Algarra, M.N. Sokolov, J. González-Platas, M.J. Fernández-Trujillo, M.G. Basallote, R. Hernández-Molina, Inorg. Chem. 48 (2009) 3639.

[47] A.G. Algarra, M.G. Basallote, M. Feliz, M.J. Fernández-Trujillo, E. Guillamón, R. Llusar, C. Vicent, Inorg. Chem. 45 (2006) 5576.

[48] M.G. Basallote, M.J. Fernández-Trujillo, M.A. Máñez, J. Chem. Soc., Dalton Trans. (2002) 3691.

[49] S. Blasco, B. Verdejo, M.P. Clares, C.E. Castillo, A.G. Algarra, J. Latorre, M.A. Máñez, M.G. Basallote, C. Soriano, E. García-España, Inorg. Chem. 49 (2010) 7016.

[50] C.E. Castillo, A.G. Algarra, M.A. Máñez, C. Duboc, M.G. Basallote, Eur. J. Inorg. Chem. (2012) 2514.

[51] A.G. Algarra, M.G. Basallote, R. Belda, S. Blasco, C.E. Castillo, J.M. Llinares, E. García-España, L. Gil, M.A. Máñez, C. Soriano, B. Verdejo, Eur. J. Inorg. Chem. 2009 (2009) 62.

[52] A.W. Addison, T.N. Rao, J. Reedijk, J. Vanrijn, G.C. Verschoor, J. Chem. Soc., Dalton Trans. (1984) 1349. 